\title{
ER-Mitochondrial Calcium Flow Underlies Vulnerability of Mechanosensory Hair Cells to Damage
}

\author{
Robert Esterberg, ${ }^{1,2}$ Dale W. Hailey, ${ }^{1,3}$ Edwin W Rubel, ${ }^{1,2,4 *}$ and David W. Raible ${ }^{1,3 *}$ \\ ${ }^{1}$ Virginia Merrill Bloedel Hearing Research Center, ${ }^{2}$ Department of Otolaryngology, Head and Neck Surgery, ${ }^{3}$ Department of Biological Structure, and \\ ${ }^{4}$ Department of Physiology and Biophysics, University of Washington, Seattle, Washington 98195
}

Mechanosensory hair cells are vulnerable to environmental insult, resulting in hearing and balance disorders. We demonstrate that directional compartmental flow of intracellular $\mathrm{Ca}^{2+}$ underlies death in zebrafish lateral line hair cells after exposure to aminoglycoside antibiotics, a well characterized hair cell toxin. $\mathrm{Ca}^{2+}$ is mobilized from the ER and transferred to mitochondria via IP ${ }_{3}$ channels with little cytoplasmic leakage. Pharmacological agents that shunt ER-derived $\mathrm{Ca}^{2+}$ directly to cytoplasm mitigate toxicity, indicating that high cytoplasmic $\mathrm{Ca}^{2+}$ levels alone are not cytotoxic. Inhibition of the mitochondrial transition pore sensitizes hair cells to the toxic effects of aminoglycosides, contrasting with current models of excitotoxicity. Hair cells display efficient ER-mitochondrial Ca ${ }^{2+}$ flow, suggesting that tight coupling of these organelles drives mitochondrial activity under physiological conditions at the cost of increased susceptibility to toxins.

Key words: lateral line; zebrafish

\section{Introduction}

The ER and mitochondria are primary regulators of $\mathrm{Ca}^{2+}$ homeostasis within the cell (Pinton et al., 2008; Giorgi et al., 2009; Murgia et al., 2009; Rizzuto et al., 2009; Grimm, 2012). Communication between ER and mitochondria is facilitated by microdomains, where $\mathrm{IP}_{3}$ receptors $\left(\mathrm{IP}_{3} \mathrm{Rs}\right)$ in the ER are juxtaposed to mitochondrial voltage-dependent anion channels (Szabadkai et al., 2006). These zones of close contact are termed mitochondrialassociated membranes (MAMs) (Vance, 1990), and function as de facto hotspots of $\mathrm{Ca}^{2+}$ transfer (Rizzuto et al., 1998; Patergnani et al., 2011; Bononi et al., 2012).

Transfer of $\mathrm{Ca}^{2+}$ between ER and mitochondria is increasingly recognized for its role in the regulation of multiple cellular processes ranging from bioenergetics (Bravo et al., 2012) to cellular dysfunction and death (Rizzuto et al., 2009; Giorgi et al., 2012; Grimm, 2012). The difference between these cellular outcomes is dependent in part on the amount of $\mathrm{Ca}^{2+}$ transferred to mitochondria. Modest increases in mitochondrial $\mathrm{Ca}^{2+}$ concentrations $\left(\left[\mathrm{Ca}^{2+}\right]_{\text {mit }}\right)$ stimulate the respiratory chain and elevate transmembrane potential $(\Delta \psi)$ across the mitochondrial

\footnotetext{
Received Jan. 20, 2014; revised May 8, 2014; accepted May 28, 2014

Author contributions: R.E., D.W.H., E.W.R., and D.W.R. designed research; R.E. and D.W.H. performed research; R.E., D.W.H., E.W.R., and D.W.R. analyzed data; R.E., D.W.H., E.W.R., and D.W.R. wrote the paper.

Work was supported by the National Institute on Deafness and Other Communication Disorders (Grants DC05987 and DC04661) and by a Ruth Kirschstein National Research Service Award (Fellowship DC012244). We thank Tor Linbo for technical assistance and Dave White for fish care.

The authors declare no competing financial interests.

*E.W.R. and D.W.R. contributed equally to this work.

Correspondence should be addressed to either of the following: Edwin W Rubel, University of Washington, Virginia Merrill Bloedel Hearing Research Center, Box 357923, Seattle, WA 98195, E-mail: rubel@uw.edu; or David W. Raible, University of Washington, Department of Biological Structure, Box 357420, Seattle, WA 98195. E-mail: draible@u.washington.edu.

DOI:10.1523/JNEUROSCI.0281-14.2014

Copyright $\odot 2014$ the authors $\quad 0270-6474 / 14 / 349703-17 \$ 15.00 / 0$
}

inner membrane (McCormack et al., 1990). More substantial $\left[\mathrm{Ca}^{2+}\right]_{\text {mit }}$ increases are cytotoxic, however, because they permanently depolarize mitochondria through long-lasting opening of the transition pore (mPTP; Nicholls, 2005, 2009; Giorgi et al., 2012). Somewhat paradoxically, the potential for $\mathrm{Ca}^{2+}$ overload is limited through mPTP openings of shorter duration that serve to gate $\Delta \psi$, a driving force behind mitochondrial $\mathrm{Ca}^{2+}$ uptake (Gunter and Pfeiffer, 1990; Stout et al., 1998; Kirichok et al., 2004; Nicholls and Chalmers, 2004; Nguyen et al., 2009).

We used the zebrafish lateral line system to study $\mathrm{Ca}^{2+}$ mobilization and flow during hair cell death. Lateral line hair cells share essential properties with inner ear hair cells, including sensitivity to many ototoxins, drugs known to cause hearing loss by killing inner ear hair cells of mammals including humans (Ton and Parng, 2005; Ou et al., 2010; Esterberg et al., 2013a). Lateral line hair cells are located on the body surface in clusters called neuromasts, providing an opportunity to monitor directly $\left[\mathrm{Ca}^{2+}\right]_{\mathrm{i}}$ changes during ototoxin-induced cell death in vivo. We demonstrated recently that disruption of $\left[\mathrm{Ca}^{2+}\right]_{i}$ homeostasis within hair cells is a critical signal and a reliable predictor of hair cell death in the intact zebrafish lateral line system after ototoxic aminoglycoside antibiotic exposure (Esterberg et al., 2013b). Here, we identify upstream disruption of ER-mitochondrial $\mathrm{Ca}^{2+}$ regulation as a necessary and sufficient signal for hair cell death due to aminoglycoside exposure.

\section{Materials and Methods}

Fish. Experiments were performed on zebrafish larvae to $5 \mathrm{~d}$ postfertilization (dpf) in E3 embryo medium ( $14.97 \mathrm{~mm} \mathrm{NaCl}, 500 \mu \mathrm{M} \mathrm{KCl}, 42 \mu \mathrm{M}$ $\mathrm{Na}_{2} \mathrm{HPO}_{4}, 150 \mu \mathrm{M} \mathrm{KH} \mathrm{PO}_{4}, 1 \mathrm{~mm} \mathrm{CaCl}$ dehydrate, $1 \mathrm{~mm} \mathrm{MgSO} \mathrm{Mg}_{4}, 0.714$ $\mathrm{mm} \mathrm{NaHCO}_{3}, \mathrm{pH} 7.2$ ) at $28.5^{\circ} \mathrm{C}$ unless otherwise indicated. Larvae were used before the stage where sex is determined in zebrafish. All experiments were approved by the University of Washington Institution Animal Care and Use Committee. 
Transgenesis constructs. $\operatorname{Tg}[$ brn3c:mGFP $]$ and $\mathrm{Tg}[\text { myo6b:cytoGCaMP3 }]^{\text {w78 }}$ have been described previously (Xiao et al., 2005; Esterberg et al., 2013b). We have shown previously that the $\mathrm{Tg}[\text { myo6b:cytoGCaMP3 }]^{\text {w78 }}$ line allows reliable detection of changes in cytoGCaMP fluorescence in the presence of ionomycin and extracellular $\mathrm{Ca}^{2+}$ concentrations as low as 70 nM (Esterberg et al., 2013b). erGCaMP and mitoGCaMP were generated through inframe fusion of GCaMP3.0 (Tian et al., 2009) with the ER targeting sequence of rat $\mathrm{CD} 3 \delta$ (Lorenz et al., 2006) or mitochondrial matrix targeting sequence of human cytochrome $\mathrm{C}$ oxidase subunit VIII (Rizzuto et al., 1989), respectively. $\mathrm{Tg}[\text { myo6b:mitoGCaMP3 }]^{\mathrm{w1} 19}$ was maintained as a transgenic line. mitoRGECO and cytoRGECO constructs were generated with RGECO (Zhao et al., 2011). D1ER was used as described previously (Palmer et al., 2004). Gateway (Invitrogen) cloning was used to generate constructs under control of the hair-cellspecific myosin6b promoter (Obholzer et al., 2008). Proper organellar localization was verified by colabeling with organelle-specific vital dyes (Mito Tracker) and/or through morphology of labeled compartments.

Tetramethylrhodamine ethyl ester labeling. Zebrafish were incubated at $28.5^{\circ} \mathrm{C}$ in $1 \mathrm{~nm}$ tetramethylrhodamine ethyl ester (TMRE; Invitrogen) in E3 medium for $30 \mathrm{~min}$ before and throughout imaging.

Photolysis of caged EGTA. mitoGCaMP embryos were injected at the 1-cell stage with $\sim 1$ $\mathrm{nl}$ of $25 \mathrm{~mm}$ NP-EGTA and mounted and uncaged at $5 \mathrm{dpf}$ with $1-2 \mathrm{~ms}$ pulses from a 405 $\mathrm{nm}$ laser, as described previously (Esterberg et al., 2013b). Imaging after uncaging was performed at $2 \mathrm{~s}$ intervals.

Texas Red exclusion. Succinimidyl esters of Texas Red (Life Technologies) were dissolved in dimethyl formamide to $2 \mathrm{mg} / \mathrm{ml}$, essentially as described previously (Steyger et al., 2003). A final concentration of $2 \mu \mathrm{M}(\sim 0.1 \%)$ was used in E3 imaging media under conditions described in Imaging and analysis, below. Under these conditions, we did not observe Texas Red entry into hair cells, consistent with previous reports (Steyger et al., 2003; Wang and Steyger, 2009; Alharazneh et al., 2011). We then subjected $\operatorname{Tg}[b r n 3 c: m G F P]$, $\mathrm{Tg}$ [myo6b:cytoGCaMP3], or $\mathrm{Tg}[$ myo6b:mitoGCaMP3 larvae to $50 \mu \mathrm{M}$ neomycin under imaging conditions described in Imaging and analysis, below.

Drug treatment. Neomycin (Sigma-Aldrich) was used at the indicated concentrations in embryo media. For all experiments, animals were exposed to aminoglycoside for $30 \mathrm{~min}$ for survival analyses at $28.5^{\circ} \mathrm{C}$ or for the amount of time indicated during imaging (typically $60 \mathrm{~min})$.

Optimal concentrations of intracellular $\mathrm{Ca}^{2+}$ inhibitors were determined by the concentrations found to confer maximal protection in the presence of $200 \mu \mathrm{M}$ neomycin (Fig. 1) as follows: $1 \mu \mathrm{M}$ xestospongin C, $500 \mathrm{~nm}$ Ru360, and $300 \mathrm{pm}$ carbonyl cyanide 4-(trifluoromethoxy)phenylhydrazone (FCCP) (all from Tocris Biosciences).

The effects of increasing concentrations of intracellular $\mathrm{Ca}^{2+}$ stimulators on hair cell survival were first determined (Fig. 1). The maximal concentrations that resulted in $<10 \%$ hair cell death were then used in the presence of the indicated concentrations of neomycinas follows: 1.25 $\mu \mathrm{M}$ thapsigargin, $4 \mu \mathrm{M}$ adenophostin $\mathrm{A}$, and $200 \mathrm{~nm}$ cyclosporin A (CsA). All agents except CsA were from Tocris Biosciences; CsA was obtained as
B

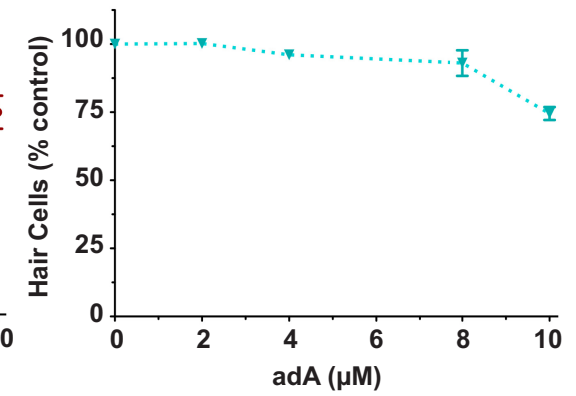

.

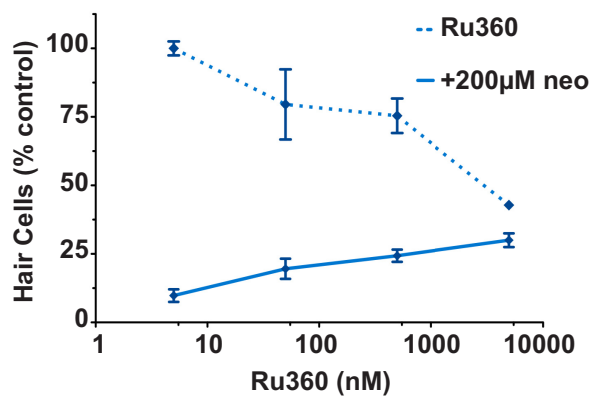

$\mathbf{F}$

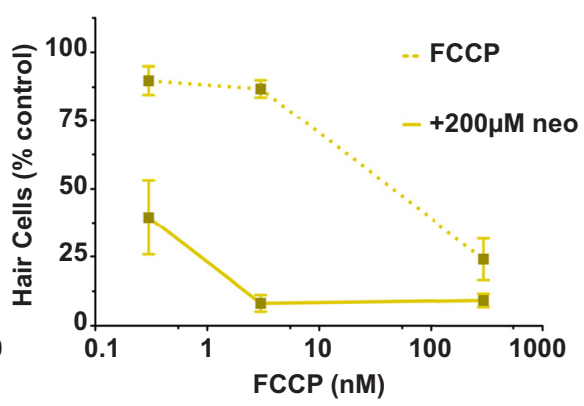

Figure 1. Optimal concentrations of agents used to manipulate ER-mitochondrial $\mathrm{Ca}^{2+}$ transfer and $\mathrm{mPTP}$ activation. $\boldsymbol{A}, \boldsymbol{B}$, Optimal concentration of thapsigargin $(\boldsymbol{A})$ and adenophostin $A(\boldsymbol{B})$ were determined by administration of either drug alone in the (dashed line). (C, D) Optimal concentrations of xestospongin C(C) and Ru360(D) were determined by lone (dashed line) or embryo medium containing $200 \mu \mathrm{m}$ neomycin (solid line). Hair cell counts are of parvalbumin-positive hair cells. Error bars indicate SD. $n=6$ neuromasts from each of 5 treated animals.

Sandimmune (Novartis) from University of Washington Drug Services. All agents except xestospongin C, Ru360, and adenophostin A were dissolved in DMSO. Xestospongin C, Ru360, and adenophostin A were dissolved in water. When appropriate, vehicle alone was used as control, which was typically $0.1 \%$ DMSO.

Hair cell counts. Animals were pretreated in $\mathrm{Ca}^{2+}$ modulators for 60 min, followed by coadministration with the specified concentration of neomycin for $30 \mathrm{~min}$. They were then washed $3 \times$ in E3, allowed to recover for $30 \mathrm{~min}$, and then fixed in 4\% PFA. Hair cells were labeled with antiparvalbumin antisera (Steyger et al., 1997) and mean hair cell counts across six neuromasts (IO4, M2, MI1, O1, $\mathrm{O}_{2}$, and OC1; Raible and Kruse, 2000) were calculated from at least five animals. Control E3 contained 0.5\% DMSO.

Imaging and analysis. Imaging and analysis were performed as described previously (Esterberg et al., 2013b). Briefly, 5 dpf zebrafish were immersed in E3 containing $0.2 \%$ MESAB (MS-222; ethyl-maminobenzoate methanesulphonate) and stabilized using a slice anchor harp (Harvard Instruments) so that neuromasts on immobilized animals had free access to surrounding media. Imaging was performed under ambient temperature, typically $24-25^{\circ} \mathrm{C}$. Baseline fluorescence readings 
A

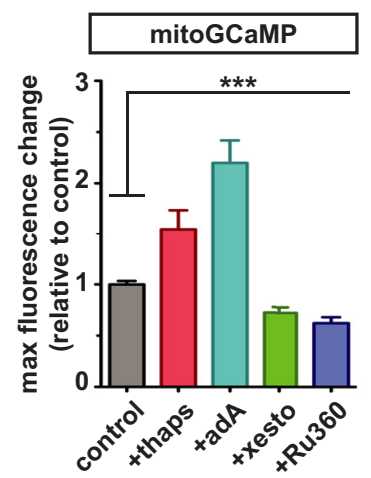

B

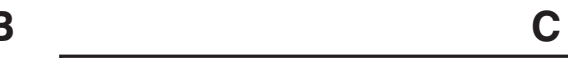

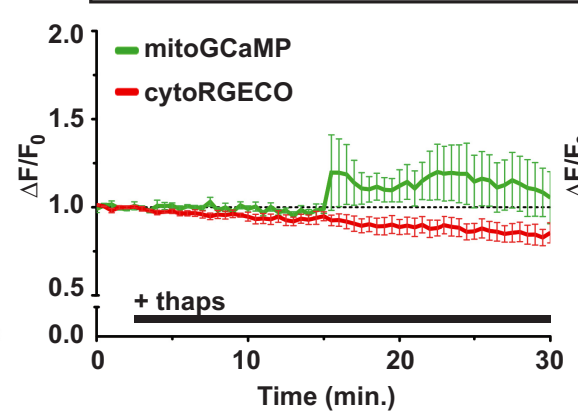

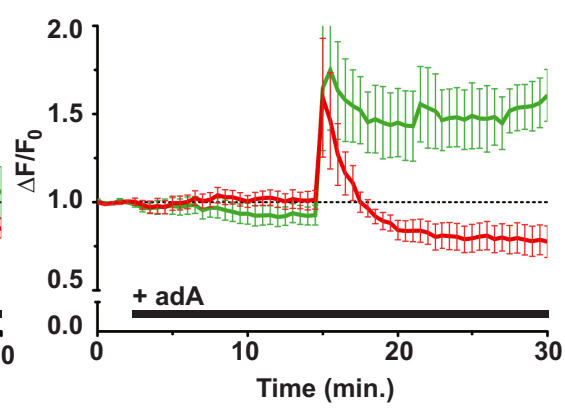

Figure 2. Efficient $\mathrm{Ca}^{2+}$ uptake by mitochondria after efflux from $\mathrm{ER}$. $A$, Modulators of $\left[\mathrm{Ca}^{2+}\right]_{\mathrm{ER}}$ alter mitochondrial $\mathrm{Ca}^{2+}$ uptake. Maximal change in mito $\mathrm{GCaMP}$ fluorescence after exposure to modulators of $\left[\mathrm{Ca}^{2+}\right]_{\mathrm{ER}} . B, C$, Dual $\mathrm{Ca}^{2+}$ indicators used within the same cell indicate that $\mathrm{ER}$ transfer $\mathrm{Ca}^{2+}$ to mitochondria with little cytoplasmic spillover. Mean transformed $\left(\Delta F / F_{0}\right)$ mitoGCaMP/cytoRGECO fluorescence intensity values in anterior lateral line hair cells exposed to thapsigargin $(\boldsymbol{B})$ or adenophostin $\mathrm{A}(\boldsymbol{C})$. Data were aligned to the onset of imaging. Comparison in $A$ is a one-way ANOVA, Dunnett post test ${ }^{* *} p<0.0001$. Error bars indicate SEM. $n=42$ control, $n=32+$ xestospongin $C, n=36+$ Ru360, $n=32+$ thapsigargin, and $n=43+$ adenophostin A. Error bars in $\boldsymbol{B}$ and $\boldsymbol{C}$ indicate SEM. In $\boldsymbol{B}, n=10+$ thapsigargin; in $\boldsymbol{C}, n=11+$ adenophostin A cells from at least 5 animals.

were taken before aminoglycoside exposure in $30 \mathrm{~s}$ intervals for $2.5 \mathrm{~min}$. Aminoglycoside was added as a $4 \times$ concentrated stock to achieve the final indicated concentration and fluorescence intensity readings were acquired in 30 s intervals for $60 \mathrm{~min}$. Images were taken using an inverted Marianas spinning disk system (Intelligent Imaging Innovations) equipped with an Evolve $10 \mathrm{MHz}$ EMCCD camera (Photometrics) and a Zeiss C-Apochromat $63 \times / 1.2$ numerical aperture water objective. Camera intensification was set to keep exposure times $<50 \mathrm{~ms}$ for GCaMP, $250 \mathrm{~ms}$ for cytoRGECO, or $100 \mathrm{~ms}$ for mitoRGECO and TMRE while keeping pixel intensity $<25 \%$ of saturation. For image collection, camera gain was set at 2 for higher resolution. For data collection, camera gain was set at 3 to minimize photobleaching. $Z$-sections were taken at $2 \mu \mathrm{m}$ intervals through the depth of the neuromast, typically $12 \mu \mathrm{m}$. GCaMP fluorescence was acquired with $488 \mathrm{~nm}$ laser and 535/30 emission filter. RGECO, TMRE, and Texas Red fluorescence were acquired with a 561 $\mathrm{nm}$ laser and a 617/73 emission filter.

For analyses, maximum intensity projections were generated and movies were auto-aligned in SlideBook software (Intelligent Imaging Innovations) to account for XY drift, typically $<50$ pixels. ROIs outlining the cell of interest were drawn by hand, enabling us to correct for individual cell movement when necessary. Cells were categorized as living or dying based on their clearance from the neuromast after $60 \mathrm{~min}$ of aminoglycoside exposure. Fluorescence intensities were calculated relative to the mean baseline intensity of each individual hair cell before aminoglycoside exposure. We observed a linear fit between maximal signal-tonoise ratios and maximal changes in fluorescence $(r=0.726$, data not shown). For each treatment condition, at least three replications were performed on different days and fluorescence intensities of no more than three cells per neuromast and two neuromasts per animal were used in analyses. Living and dying cells were chosen randomly for analysis at the end of each time lapse. For imaging during $\mathrm{Ca}^{2+}$ modulation, animals were exposed to modulators $30 \mathrm{~min}$ before recording of baseline fluorescence and coadministered with neomycin at the indicated concentrations.

Statistics. GraphPad Prism 5.0 Software was used for all statistical analyses except cross-correlations. Analyses and post hoc tests are indicated in figure legends. Cross-correlation analyses were performed in either $R$ or Microsoft Excel.

\section{Results}

Efficient uptake of $\mathrm{Ca}^{2+}$ drives mitochondrial activity within lateral line hair cells

Mechanosensory hair cells are densely packed with mitochondria to accommodate their high metabolic load. We investigated whether hair cell mitochondrial activity is regulated by ERmitochondrial $\mathrm{Ca}^{2+}$ exchange using transgenic zebrafish containing mitochondrial matrix-targeted GCaMP3 under the control of the hair-cell-specific myo6b promoter [ $\mathrm{Tg}($ myo6b:mitoGCaMP3), which is hereafter referred to as mitoGCaMP]. Optimal concentrations of pharmacological agents known to modulate ER $\mathrm{Ca}^{2+}$ concentrations $\left(\left[\mathrm{Ca}^{2+}\right]_{\mathrm{ER}}\right)$ were first determined to be minimally toxic to hair cells over the course of imaging (Fig. 1) and were subsequently applied to mitoGCaMP larvae to determine their effect on $\left[\mathrm{Ca}^{2+}\right]_{\text {mit }}$ (Fig. 2). All agents tested altered $\left[\mathrm{Ca}^{2+}\right]_{\text {mit }}$ in a manner consistent with ER-mitochondrial $\mathrm{Ca}^{2+}$ flow (Fig. 2A). Inhibition of the ER SERCA pump with thapsigargin (Marks, 1997) increased maximal mitoGCaMP fluorescence $\sim 50 \%(p<0.001)$, whereas activation of $\mathrm{IP}_{3}$ Rs with adenophostin A (Mak et al., 2001) increased maximal mitoGCaMP fluorescence $\sim 100 \%(p<0.001)$. Conversely, inhibition of $\mathrm{IP}_{3}$ receptors with xestospongin C (Gafni et al., 1997) reduced mitoGCaMP fluorescence $\sim 30 \%(p<0.001)$ and blocking the mitochondrial uniporter with the inhibitor Ru360 (Matlib et al., 1998; Zazueta et al., 1999) reduced mitoGCaMP fluorescence $\sim 40 \%(p<0.001)$.

$\mathrm{Ca}^{2+}$ originating from the ER is thought to be first transferred to cytoplasm, where it is then taken up by mitochondria (Patergnani et al., 2011). To monitor $\mathrm{Ca}^{2+}$ flow between cytoplasm and mitochondria directly within the same hair cell, we generated transgenic zebrafish containing a hair-cell-specific cytoplasmic variant of the genetically encoded red $\mathrm{Ca}^{2+}$ indicator RGECO [ Tg(myo6b:RGECO); hereafter referred to as cytoRGECO] (Zhao et al., 2011). Hair cells exposed to thapsigargin showed a slight increase in fluorescence of the cytoplasmic $\mathrm{Ca}^{2+}$ indicator while mitochondrial fluorescence rose $\sim 20 \%$ above baseline levels (Fig. 2B). Stimulation of $\mathrm{IP}_{3}$ Rs with adenophostin A resulted in a transient cytoplasmic $\mathrm{Ca}^{2+}$ spike corresponding with the onset of increased mitochondrial $\mathrm{Ca}^{2+}$ accumulation, followed by a reduction in fluorescence (Fig. 2C). These results suggest that, in hair cells, mitochondria efficiently buffer $\mathrm{Ca}^{2+}$ during release from the ER.

Mitochondrial $\mathrm{Ca}^{2+}$ uptake is tightly cross-regulated with $\Delta \psi$ under physiological conditions (Brookes et al., 2004). We measured $\Delta \psi$ in lateral line hair cells using the potentiometric mitochondrial dye TMRE (Mitra and Lippincott-Schwartz, 2010; Brand and Nicholls, 2011; Perry et al., 2011; Fig. 3). Application of the protonophore uncoupler FCCP or the ATP synthase inhibitor oligomycin A induced corresponding dose-dependent decreases or increases, respectively, in TMRE fluorescence (Fig. 
$3 A, B)$. Treatment with CsA gradually increased mitochondrial TMRE fluorescence (Fig. $3 A, B$ ). This behavior is consistent with a role of CsA-sensitive transient mPTP opening in alleviation of $\Delta \psi$ (Ichas et al., 1997; Smaili and Russell, 1999; Li et al., 2004; Wang et al., 2008; Korge et al., 2011; Ma et al., 2011; Wang et al., 2012). Modulation of TMRE fluorescence with either FCCP or CsA altered mitoGCaMP fluorescence in a manner consistent with cross-regulation of $\left[\mathrm{Ca}^{2+}\right]_{\text {mit }}$ and $\Delta \psi$ (Fig. 3C; Gunter and Pfeiffer, 1990; Stout et al., 1998; Kirichok et al., 2004; Nicholls and Chalmers, 2004; Nguyen et al., 2009).

To determine whether ER-mitochondrial $\mathrm{Ca}^{2+}$ exchange altered $\Delta \psi$ in hair cells, as would be predicted if $\left[\mathrm{Ca}^{2+}\right]_{\text {mit }}$ regulates mitochondrial respiration, we measured TMRE fluorescence of all hair cells within an entire neuromast after a 60 min agent incubation. TMRE fluorescence within hair cells exposed to xestospongin C, Ru360, or adenophostin A alone was not significantly different from controls (Fig. 4A). TMRE fluorescence was elevated after prolonged exposure to CsA $(p<0.001)$. Coexposure to both CsA and adenophostin A resulted in a synergistic effect on TMRE fluorescence $(p<0.001)$.

We also measured changes mitochondrial $\mathrm{Ca}^{2+}$ uptake and $\Delta \psi$ after a brief increase in cytoplasmic $\mathrm{Ca}^{2+}$. We used caged EGTA preloaded with $\mathrm{Ca}^{2+}$ (caEGTA) to elevate $\left[\mathrm{Ca}^{2+}\right]$ transiently after exposure to near UV (405 nm) light (Ellis-Davies et al., 1996). mitoGCaMP fluorescence was reliably elevated $\sim 20 \%$ within $30 \mathrm{~s}$ after $405 \mathrm{~nm}$ exposure $(p<0.001$; Fig. $4 B)$, but not elevated in hair cells receiving caEGTA or $405 \mathrm{~nm}$ light alone. In these same cells, TMRE fluorescence increased $\sim 10 \%$ compared with controls with UV and caEGTA exposure (Fig. 4C). TMRE fluorescence then rapidly dropped below baseline (Fig. 4C), consistent with the rapid mitochondrial depolarization observed in other contexts after increased $\left[\mathrm{Ca}^{2+}\right]_{\text {mit }}$ (Loew et al., 1994; Hajnóczky et al., 1995; Ichas et al., 1997; Duchen et al., 1998; Csordás et al., 1999; Nguyen et al., 2009). Application of Ru360 abolished TMRE changes after $\mathrm{Ca}^{2+}$ uncaging (Fig. 4C), confirming that mitochondrial $\mathrm{Ca}^{2+}$ uptake was necessary for $\Delta \psi$ changes. Together, these data indicate that even transient increases in mitochondrial $\mathrm{Ca}^{2+}$ can alter mitochondrial activity within hair cells.

\section{Mitochondria accumulate $\mathrm{Ca}^{2+}$ in dying hair cells after aminoglycoside exposure}

Mitochondrial toxicity is a common feature of cells exposed to aminoglycosides in hair cells (Dehne et al., 2002; Owens et al., 2007; Hobbie et al., 2008; Jensen-Smith et al., 2012) and in more robust cell types (Kalghatgi et al., 2013). We investigated whether mitochondrial $\mathrm{Ca}^{2+}$ stores are altered by exposure to this class of ototoxins. We exposed zebrafish to $50 \mu \mathrm{M}$ neomycin, a concentration that reliably induces death in $\sim 40 \%$ of hair cells within each neuromast (Harris et al., 2003), allowing us to compare mitoGCaMP signals over time in adjacent living and dying cells in the same environment (Movie 1). Time-lapse images from a representative neuromast are shown in Figure $5 \mathrm{~A}$ and corresponding fluorescence traces from individual living and dying
B

C

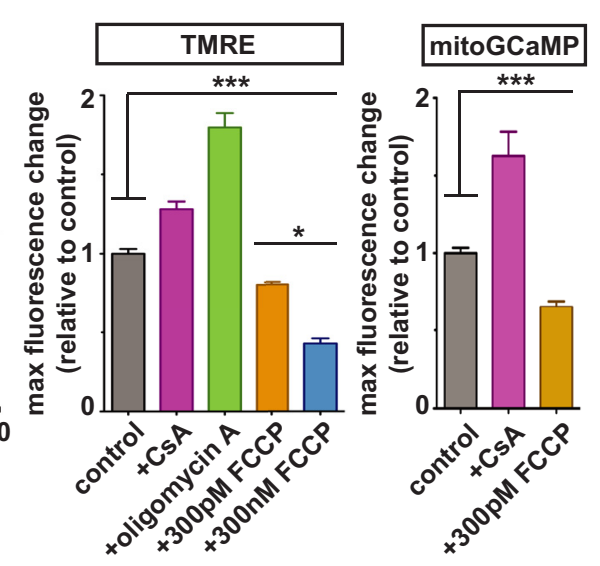

Figure 3. Validation of pharmacological agents and conditions used to monitor mitochondrial $\mathrm{Ca}^{2+}$ uptake and $\Delta \psi$ in anterior 0.05. Error bars indicate SEM. In $\boldsymbol{A}$ and $\boldsymbol{B}, n=75$ control, $n=29300 \mathrm{pm} \mathrm{FCCP}, n=30300 \mathrm{~nm} \mathrm{FCCP}, n=38$ oligomycin $A$, and $n=$ $=34 \mathrm{CsA}$, and $n=57$ FCCP. Data were taken from at least 5 animals and 3 experimental runs.

cells are shown in Figure 5B. Living and dying cells exhibited distinctly different behaviors: mitoGCaMP fluorescence within dying cells increased, plateaued, and then crashed as cells died (Fig. $5 A, B$, cells $1,3,4$, and 5 ), wherease no increases were observed in living cells (Fig. $5 A, B$, cells 2 and 6). Differences in maximal fluorescence changes between living and dying cells were observed consistently between neuromasts in the same fish and between fish; dying cells averaged $120 \%$ increase $(p<0.001)$ and living cells showed no significant changes compared with controls (Fig. 5C). No dose-dependent relationship was observed between fluorescence intensity and neomycin concentration in dying cells $(r=0.03, p=0.20$; Fig. $5 C)$. Changes in mitoGCaMP signal after aminoglycoside exposure was $100 \%$ predictive of hair cell fate. Fluorescence of cpGFP, the fluorophore backbone of GCaMP lacking $\mathrm{Ca}^{2+}$-binding EF hand domains (Nakai et al., 2001), or cpYFP, a pH-sensitive variant of cpGFP (Wang et al., 2008; Schwarzlander et al., 2011), was not significantly different from controls (Fig. 5C). These results suggest that mitoGCaMP fluorescence is due to increased mitochondrial $\mathrm{Ca}^{2+}$ uptake instead of other potential responses such as osmolarity or $\mathrm{pH}$ changes independent of $\mathrm{Ca}^{2+}$.

The onset of dramatic $\left[\mathrm{Ca}^{2+}\right]_{\text {mit }}$ changes within dying hair cells and the timing of their ultimate clearance from the neuromast are asynchronous with respect to the onset of aminoglycoside exposure. We found no evidence for relationships between cell positions or initial baseline intensities and the onset or duration of these changes. In contrast, alignment of mitoGCaMP fluorescence signals within dying cells to their point of clearance from the neuromast revealed a consistent pattern of behavior (Fig. 5D). Fluorescence gradually increased beginning $\sim 45 \mathrm{~min}$ before cell clearance, with the half-maximal change in fluorescence occurring $\sim 15$ min before clearance (Fig. $5 D$ ). These results suggest that stereotypical mitochondrial $\mathrm{Ca}^{2+}$ responses may be central to hair cell death.

$\mathrm{ER} \mathrm{Ca}^{2+}$ stores are disrupted after aminoglycoside exposure in dying hair cells

Because ER-mitochondrial $\mathrm{Ca}^{2+}$ transfer is an initiator of cell death in several in vitro systems, we measured $\mathrm{ER} \mathrm{Ca}^{2+}$ changes 
A

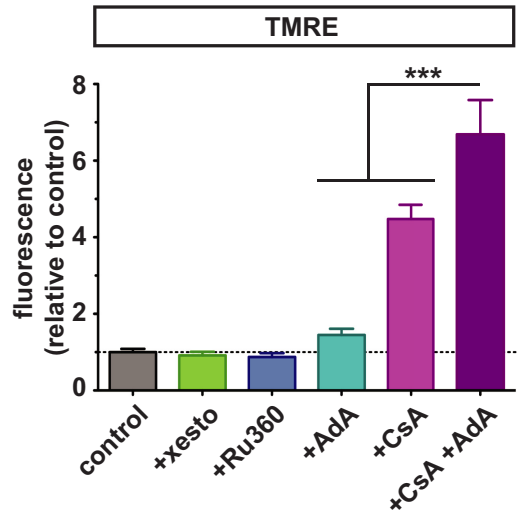

B

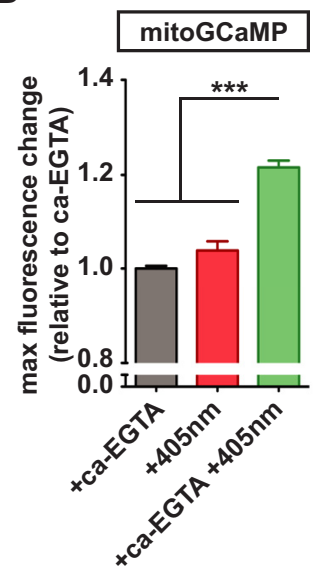

C

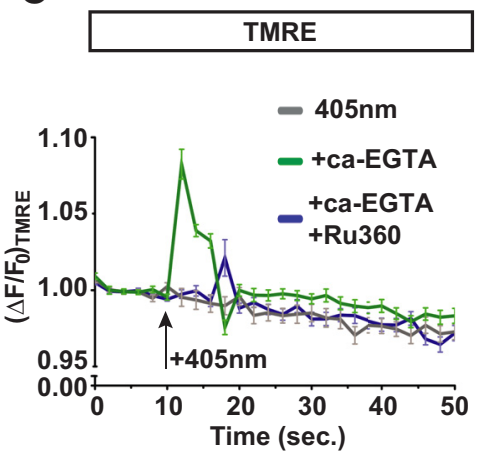

Figure 4. Mitochondrial $\mathrm{Ca}^{2+}$ uptake drives mitochondrial activity. $\boldsymbol{A}$, TMRE fluorescence after 60 min exposure to modulators of $\left[\mathrm{Ca}^{2+}\right]_{\mathrm{ER}}$ or $\left[\mathrm{Ca}^{2+}\right]_{\text {mit }} \boldsymbol{B}, \mathrm{Maximal}$ change in mitoGCaMP fluorescence after injection of caEGTA and exposure to $405 \mathrm{~nm}$ light. $C$, Mean transformed $\left(\Delta F / F_{0}\right)$ TMRE fluorescence intensity values in anterior lateral line hair cells injected with caEGTA and exposed to $405 \mathrm{~nm}$ light. In $\boldsymbol{A}$ and $\boldsymbol{B}$, comparisons are one-way ANOVAs, Dunnett post test ${ }^{* *} p<0.0001$. Error bars indicate $\mathrm{SEM}$. In $\boldsymbol{A}, n=10$ neuromasts of each group, all from at least 5 animals. In $\boldsymbol{B}, n=10405 \mathrm{~nm}, n=21$ caEGTA, and $n=27405 \mathrm{~nm}+$ caEGTA; in $\boldsymbol{C}, n=51405 \mathrm{~nm}, n=66405 \mathrm{~nm}+$ caEGTA, and $n=57405 \mathrm{~nm}+$ caEGTA + Ru360 cells from at least 5 animals. Error bars indicate SEM.

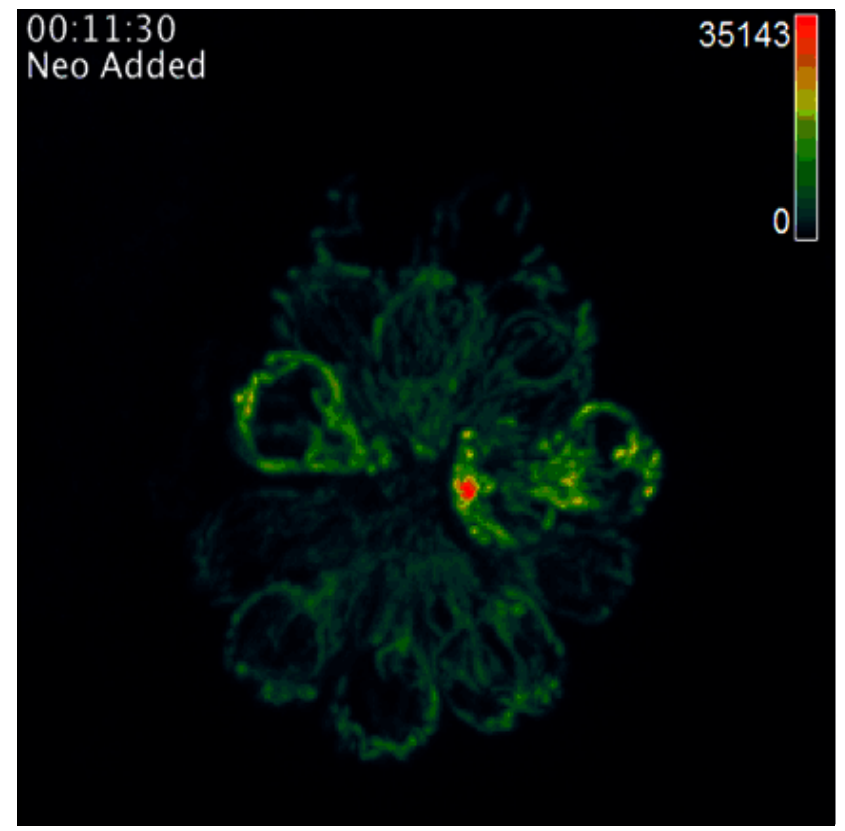

Movie 1. Dynamic changes in mitochondrial $\mathrm{Ca}^{2+}$ after neomycin exposure. Heat-mapped time-lapse movie of a $\mathrm{Tg}$ (my06:mitoG(aMP3) anterior lateral line neuromast exposed to $50 \mu \mathrm{M}$ neomycin. Time of neomycin addition to embryo medium is indicated (h:min:sec).

using GCaMP3 targeted to the ER lumen of hair cells [ $T g(m y o 6 b$ : erGCaMP3); hereafter referred to as erGCaMP]. A representative time-lapse experiment is shown in Movie 2. Time-lapse images of a neuromast exposed to $50 \mu \mathrm{M}$ neomycin are shown in Figure $6 \mathrm{~A}$ and corresponding trace data are shown in Figure $6 B$. As with mitoGCaMP, living and dying cells exhibited distinctly different behaviors after neomycin exposure. erGCaMP fluorescence within living cells remained largely stable (Fig. $6 A, B$, cells 1 and 5 ) and maximal fluorescence changes did not differ significantly from controls or dying cells expressing ER-targeted cpGFP (Fig. $6 C)$. Fluorescence of dying cells decreased $\sim 30 \%$ ( $p<0.001$; Fig. $6 C)$, indicating a reduction of $\left[\mathrm{Ca}^{2+}\right]_{\mathrm{ER}}$. Unlike mitoGCaMP, however, we observed statistically significant differences in max- imal fluorescence changes between cells exposed to 50 or $100 \mu \mathrm{M}$ neomycin compared with those exposed to 200 or $400 \mu \mathrm{M}$ neomycin $(p<0.05$; Fig. $6 C$ ). Moreover, our data indicate that a maximal decrease in erGCAMP fluorescence is highly correlated with exposure to increasing concentrations of neomycin $(r=$ $0.92 ; p<0.0001)$.

As with mitoGCaMP, a clear trend in erGCaMP behavior was observed after alignment to cell clearance (Fig. 6D). Initial decrease in erGCaMP fluorescence first appeared to occur an average of $50 \mathrm{~min}$ before cell clearance, slightly before the onset of observed mitoGCaMP fluorescence changes. Half-maximal fluorescence change occurred on average $22 \mathrm{~min}$ before clearance, before that of mitoGCaMP (Fig. 6D). Similar behavior was observed with the ER-targeted $\mathrm{Ca}^{2+}$ sensor D1ER (Fig. 7), which possesses a lower $\mathrm{Ca}^{2+}$-binding affinity suitable for monitoring $\mathrm{Ca}^{2+}$ under conditions of high $\left[\mathrm{Ca}^{2+}\right]$ (Palmer et al., 2004). Overall, the differences in timing of events suggest that $\mathrm{ER} \mathrm{Ca}^{2+}$ mobilization occurs before mitochondrial accumulation.

\section{Direct visualization of compartmental $\mathrm{Ca}^{2+}$ changes during} aminoglycoside-induced hair cell death

To monitor distinct compartmental $\mathrm{Ca}^{2+}$ flow during aminoglycoside-induced hair cell death directly, we used spectrally distinct combinations of RGECO and GCaMP targeted to the ER, mitochondria, and cytoplasm. The behavior of either mitoRGECO or cytoRGECO alone resembled that of their respective GCaMP variants (Fig. 8). The combinatorial expression of erGCaMP and mitoRGECO in the same hair cells enabled us to track $\left[\mathrm{Ca}^{2+}\right]_{\mathrm{ER}}$ and $\left[\mathrm{Ca}^{2+}\right]_{\text {mit }}$ simultaneously (Fig. $4 A-C$, Movie 3). After $400 \mu \mathrm{M}$ neomycin exposure, a concentration that kills all mature hair cells within the neuromast (Santos et al., 2006), a half-maximal change of erGCaMP fluorescence occurred $\sim 30 \mathrm{~s}$ before the half-maximal change of mitoRGECO. This relationship is illustrated with data from a single cell (Fig. 9A) and with multiple cells aligned to cell clearance (Fig. 9B). In each sample, the initial decrease in erGCaMP fluorescence occurred either in the same $30 \mathrm{~s}$ imaging interval or slightly before increased mitoRGECO fluorescence. Cross-correlation analysis of paired data supported the notion of a strong negative relationship between erGCaMP fluorescence and mitoRGECO fluorescence, in which 


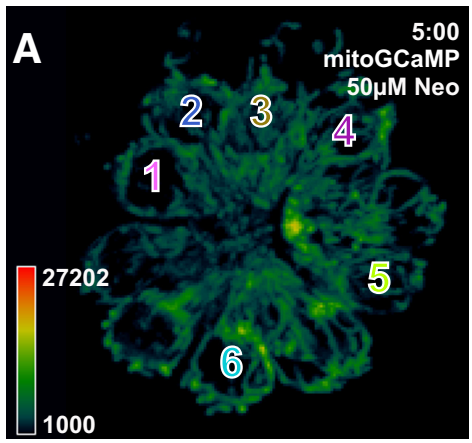

B

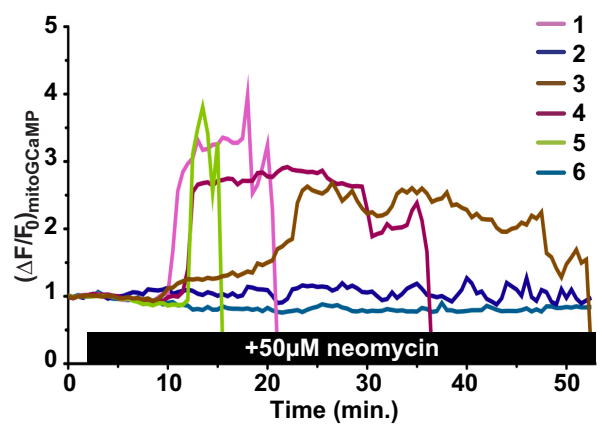

C

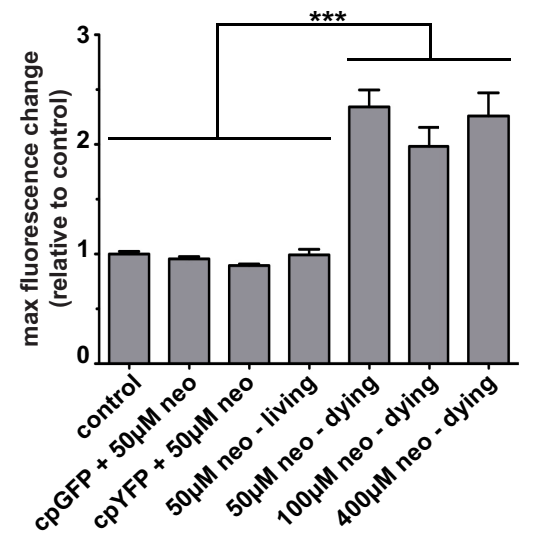

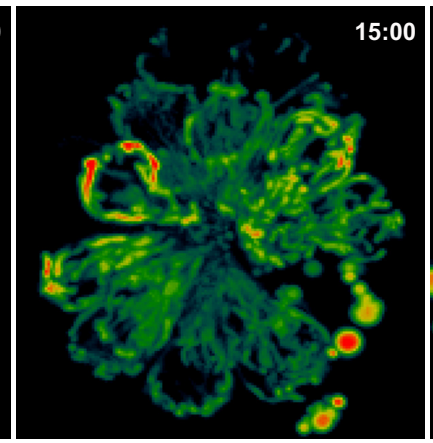

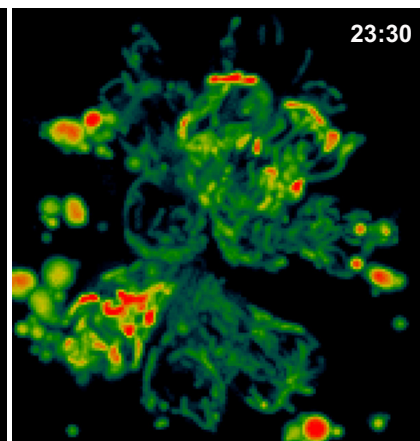

D

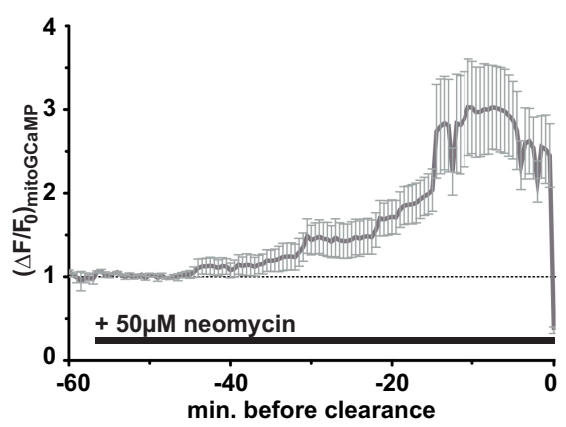

Figure 5. Mitochondrial $\mathrm{Ca}^{2+}$ uptake during aminoglycoside-induced hair cell death. $A$, Heat-mapped time-lapse images of mitoGCaMP within an anterior lateral line neuromast exposed to 50 $\mu \mathrm{m}$ neomycin. Two living and four dying cells are indicated with numbers. (ells 2 and 6 lived, whereas the remaining outlined cells die after neomycin exposure. Time indicates (min:sec) after neomycin exposure. $A$ is taken from Movie 1. $\boldsymbol{B}$, Transformed $\left(\Delta F / F_{0}\right)$ fluorescence intensity data of individual mitoGCaMP cells in $A$. C, Maximal mitoGCaMP fluorescence change in surviving or dying cells exposed to increasing concentrations of neomycin. Because camera gain settings for image presentation are different from the ones used for data collection, values from $\boldsymbol{B}$ are not included in C. D, Mean transformed $\left(\Delta F / F_{0}\right)$ mitoGCaMP intensity data in dying hair cells exposed to $50 \mu \mathrm{m}$ neomycin. Data for each cell is aligned to the time at which it was cleared from the neuromast. One-way ANOVA, Dunnett post test ${ }^{* * *} p<0.0001$. Error bars indicate SEM. $n=15$ cells from 3 neuromasts/animal and 5 animals. See also Movie 1.

\section{$00: 19: 30$ Neo Added}

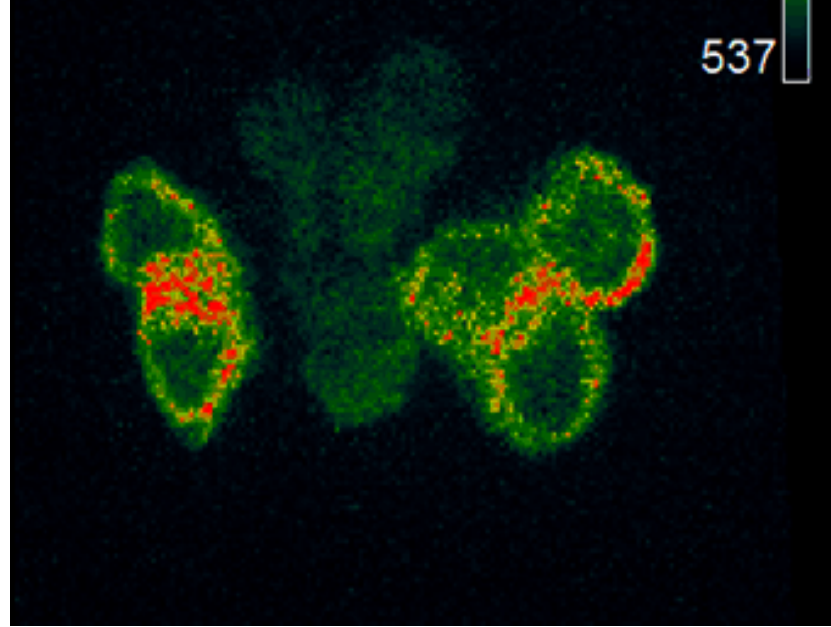

Movie 2. Dynamic changes in $\mathrm{ER} \mathrm{Ca}^{2+}$ after neomycin exposure. Heat-mapped time-lapse movie of a $\operatorname{Tg}$ (myo6:erGCaMP3) anterior lateral line neuromast exposed to $50 \mu \mathrm{m}$ neomycin. Time of neomycin addition to embryo medium is indicated (h:min:sec). Dying cells are indicated with arrows.
mitoRGECO fluorescence increased $\sim 1-5$ min after erGCaMP decreased (maximal $r$ was at -4 min, where $r=-0.557 ; p=$ 0.0125; Fig. 9C).

We showed previously that, in dying cells, cytoGCaMP showed a signal that reached a half-maximal change in fluorescence $\sim 3$ min before cell clearance (Esterberg et al., 2013b), several minutes after the observed changes in ER and mitoGCaMP. We evaluated directly the relationship between $\left[\mathrm{Ca}^{2+}\right]_{\text {mit }}$ and cytoplasmic $\mathrm{Ca}^{2+}$ concentrations $\left(\left[\mathrm{Ca}^{2+}\right]_{\text {cyt }}\right.$ ) by expressing cytoRGECO in a mitoGCaMP background (Fig. 9D-F, Movie 4). In hair cells exposed to $400 \mu \mathrm{M}$ neomycin, half-maximal change in mitoGCaMP fluorescence occurred well before that of cytoRGECO (Fig. 9D,E). Cross-correlation analysis again supported a strong relationship between the 2 , where mitoGCaMP increased $\sim 2-8$ min before increased cytoRGECO signals (maximal $r$ was at $4.5 \mathrm{~min}$, where $r=0.717$; $p=0.0013$; Fig. 9F).

Analysis of fluorescence changes between erGCaMP and cytoRGECO was also performed to evaluate the possibility of the ER as a direct source of cytoplasmic $\mathrm{Ca}^{2+}$ peaks in dying cells. Increased cytoRGECO signals were not observed until well after decreases in erGCaMP fluorescence, at $\sim 6-12 \mathrm{~min}$ (data not shown).

Elevated $\left[\mathrm{Ca}^{2+}\right]_{\text {mit }}$ precedes membrane permeabilization during aminoglycoside-induced hair cell death

Hair cells undergo phospholipid reorganization of the plasma membrane in response to aminoglycosides, even at sublethal exposures (Goodyear et al., 2008). We sought to determine whether 


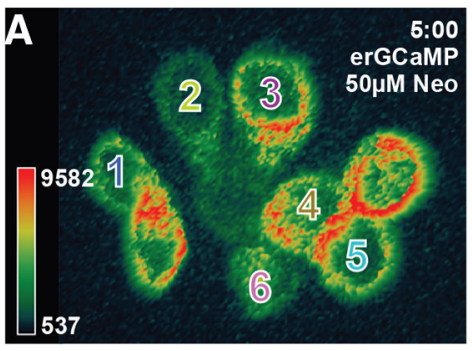

B

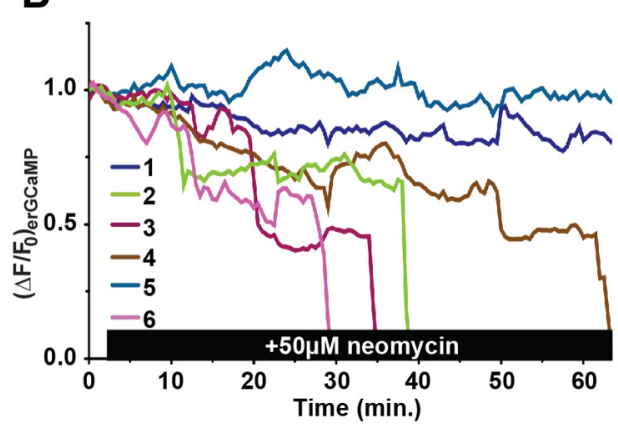

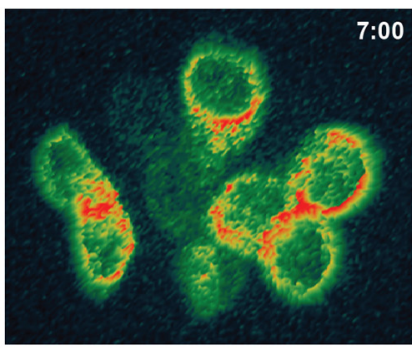

C

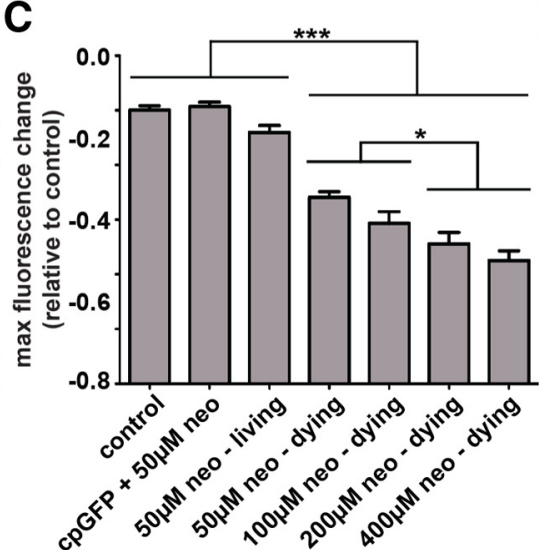

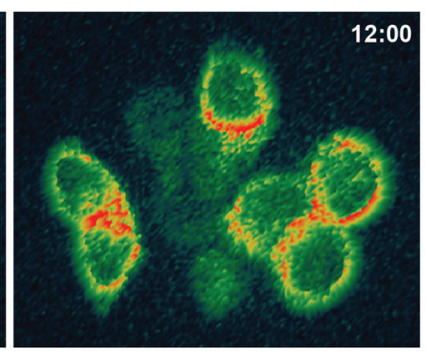

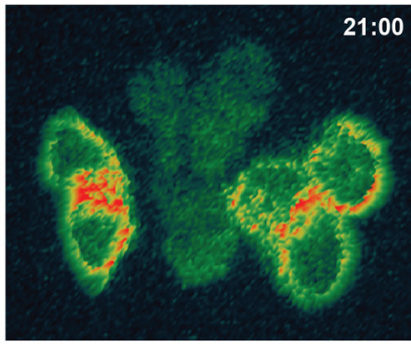

D

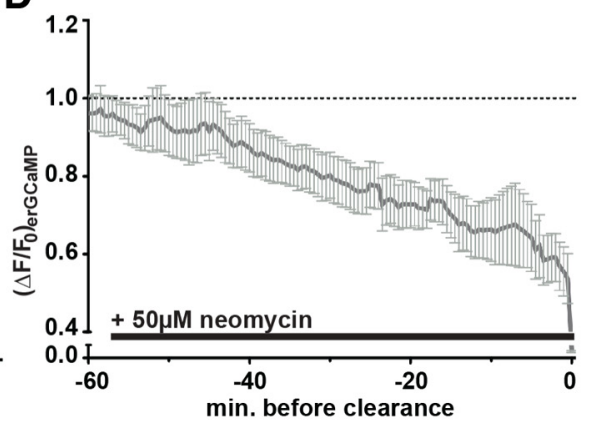

Figure 6. $\mathrm{Ca}^{2+}$ efflux from the ER during aminoglycoside-induced hair cell death. $\boldsymbol{A}$, Heat-mapped time-lapse images of erGCaMP within an anterior lateral line neuromast exposed to $50 \mu \mathrm{M}$ neomycin. Two living and four dying cells are indicated with numbers. (ells 1 and 5 lived, whereas the remaining outlined cells died after neomycin exposure. Time indicates (min:sec) after neomycin exposure. Panel in $\boldsymbol{A}$ is taken from Movie 2. $\boldsymbol{B}$, Transformed $\left(\Delta F / F_{0}\right)$ fluorescence intensity data of individual erGCaMP cells in $\boldsymbol{A}$. $\boldsymbol{C}$, Maximal erGCaMP fluorescence change in surviving or dying cells exposed to increasing concentrations of neomycin. Note the differences in maximal erGCaMP fluorescence between the 50 and $100 \mu m$ neomycin exposure groups compared with the 200 and 400 $\mu \mathrm{m}$ neomycin exposure groups. Because camera gain settings for image presentation are different from the ones used for data collection, values from $\boldsymbol{B}$ are not included in $\boldsymbol{C}$. $\boldsymbol{D}$, Mean transformed $\left(\Delta F / F_{0}\right)$ erGCaMP intensity data in dying hair cells exposed $50 \mu \mathrm{m}$ neomycin. One-way ANOVA, Dunnett post test ${ }^{* * *} p<0.0001,{ }^{*} p<0.05$. Error bars indicate SEM. $n=15$ cells from 3 neuromasts/animal and 5 animals. See also Movie 2.

A

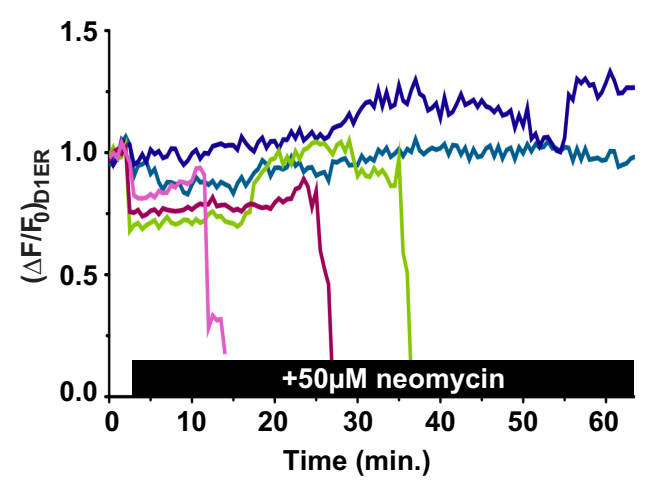

B

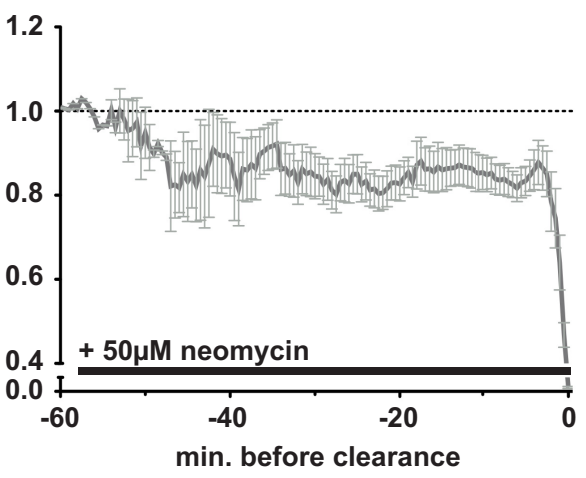

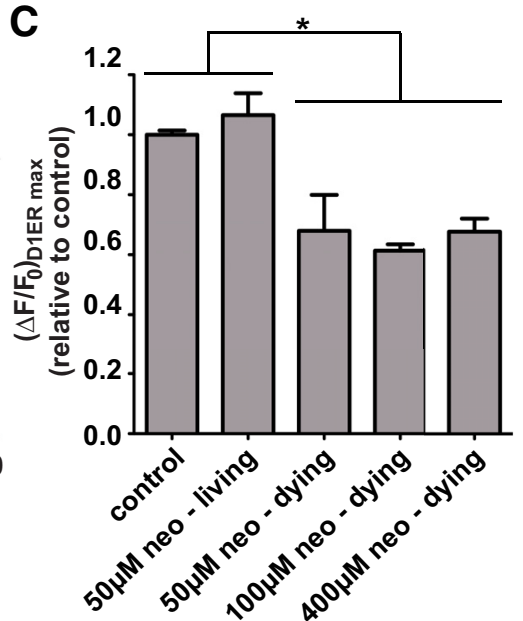

Figure 7. $\quad \mathrm{Ca}^{2+}$ efflux from the ER during aminoglycoside-induced hair cell death monitored with D1ER. $A$, Transformed $\left(\Delta F / F_{0}\right)$ fluorescence intensity data of individual D1ER cells exposed to $50 \mu \mathrm{m}$ neomycin. Blue-shaded traces are of cells that live after neomycin exposure. B, Mean D1ER intensity data of dying hair cells exposed to $50 \mu m$ neomycin. $C$, Maximal D1ER fluorescence change in surviving or dying cells exposed to increasing concentrations of neomycin. C, Kruskal-Wallis test ${ }^{*} p<0.05$. Error bars indicate SEM. $n=5$ control, $n=2050 \mu \mathrm{m}$ neomycin-living, $n=1150$ $\mu \mathrm{m}$ neomycin-dying, $n=5100 \mu \mathrm{m}$ neomycin, and $n=15400 \mu \mathrm{m}$ neomycin cells from at least 5 animals. In $C$, error bars indicate SEM and $n=11$ cells from at least 5 animals.

extracellular $\mathrm{Ca}^{2+}$ contributes to compartmental $\mathrm{Ca}^{2+}$ increases in dying cells as they lose membrane integrity. In lieu of the fact that normally "cell-impermeant" dyes, including those belonging to the cyanine family of nucleic acid stains (SYTOX, TO-PRO, TOTO, etc.), robustly label intact hair cells (data not shown; also see Chiu et al., 2008), we used Texas Red in our media to evaluate cellular permeability. Texas Red is not normally taken up by viable hair cells (Steyger et al., 2003; Wang and Steyger, 2009;
Alharazneh et al., 2011). Consistent these studies, we found that Texas Red was excluded from intact lateral line hair cells (data not shown). After exposure to $50 \mu \mathrm{M}$ neomycin, Texas Red entered the cytoplasm of $100 \%$ of dying hair cells before the point of clearance from the neuromast (for an example, see Fig. 10A) and Texas Red signal was excluded from all surviving cells throughout the entirety of imaging $(n>400$ cells from $>20$ neuromasts). 
A

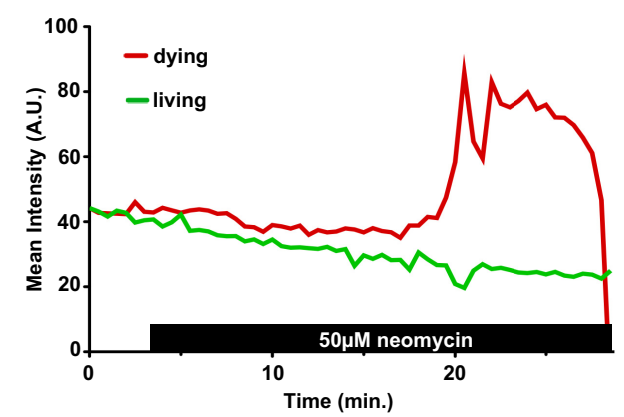

B

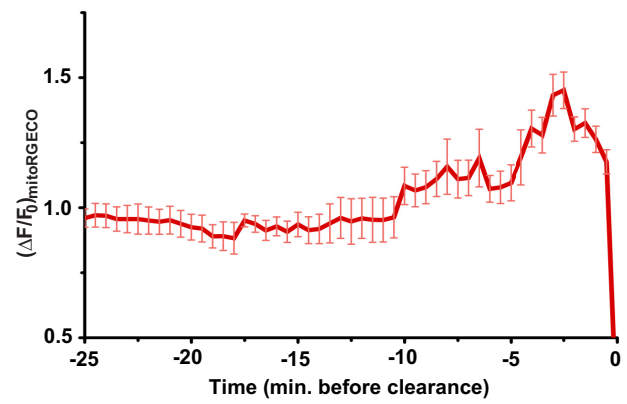

C

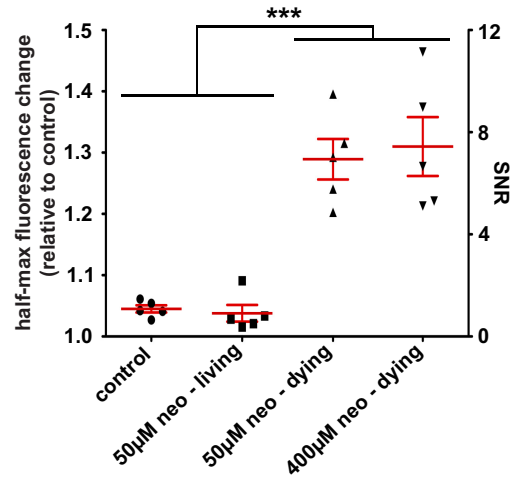

D

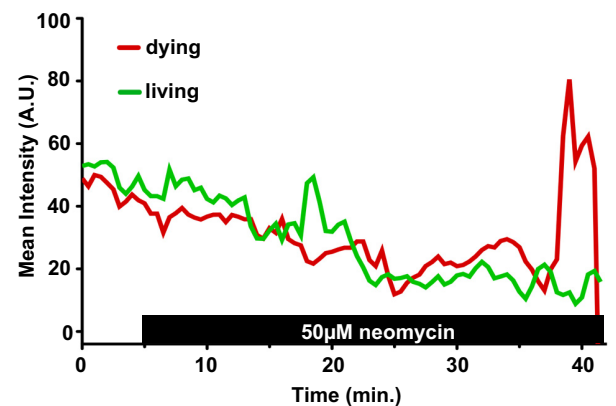

$\mathbf{E}$

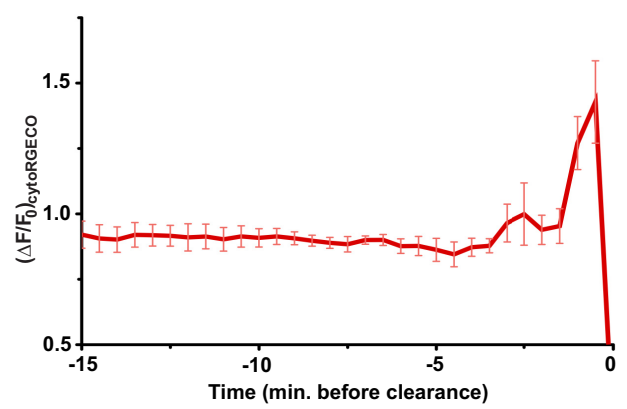

$\mathbf{F}$

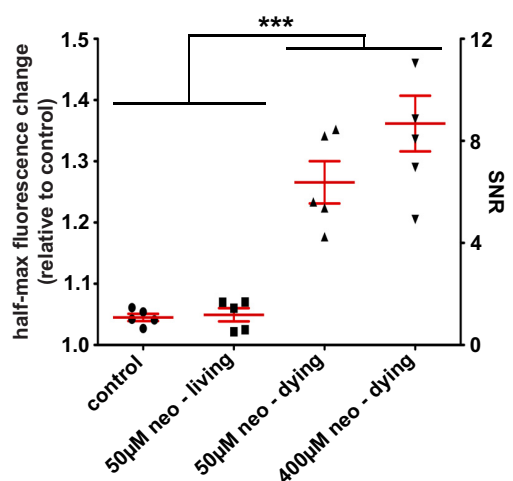

Figure 8. Validation of mitoRGECO and cytoRGECO constructs. $A-C$, Validation of mitoRGECO within lateral line hair cells. $A$, Raw fluorescence intensity data of individual mitoRGECO hair cells exposed to $50 \mu$ m neomycin. Intensities from living and dying cells were taken from hair cells located within the same neuromast. $\boldsymbol{B}$, Mean intensity data of dying mitoRGECO hair cells exposed to $50 \mu \mathrm{m}$ neomycin aligned to the time at which each hair cell was cleared from the neuromast. C, Maximal mitoRGEC 0 fluorescence changes compared between living and dying cells exposed to 50 and $400 \mu \mathrm{m}$ neomycin. One-way ANOVA, Dunnett post test ${ }^{* * *} p<0.0001$. $\boldsymbol{D}-\boldsymbol{F}$, Validation of cytoRGECO within lateral line hair cells. $\boldsymbol{D}$, Raw fluorescence intensity data of individual cytoRGECO hair cells administered $50 \mu \mathrm{m}$ neomycin. Intensities from living and dying cells were taken from hair cells located within the same neuromast. $\boldsymbol{E}$, Mean intensity data of dying cytoRGECO hair cells exposed to $50 \mu \mathrm{m}$ neomycin aligned to the time at which each hair cell was cleared from the neuromast. $\boldsymbol{F}$, Maximal cytoRGECO fluorescence changes compared between living and dying cells exposed to 50 and $400 \mu \mathrm{m}$ neomycin. One-way ANOVA, Dunnett post test ${ }^{* *} p<0.0001$. Error bars indicate SEM and $n=5$ from at least three experimental runs.
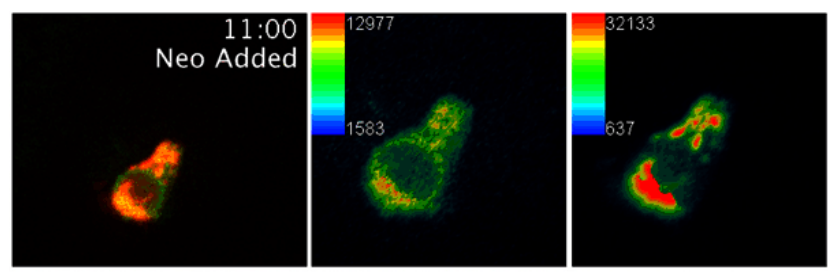

Movie 3. Dynamic changes in ER $\mathrm{Ca}^{2+}$ relative to mitochondrial $\mathrm{Ca}^{2+}$ during aminoglycoside-induced hair cell death. Time-lapse movie of a single $\operatorname{Tg}($ myo6:erGCaMP3); my06:mitoRGECO) anterior lateral line hair cell exposed to $400 \mu \mathrm{m}$ neomycin. Left, Pseudocolored erGCaMP in green and mitoRGECO in red. Middle, Heat-mapped erGCaMP. Right, Heatmapped mitoRGECO. Time of neomycin addition to embryo medium is indicated (min:sec).
We next analyzed mitoGCaMP and cytoGCaMP behavior in the presence of Texas Red to monitor their behavior relative to dye entry in dying cells. After exposure to $50 \mu \mathrm{M}$ neomycin, increases in mitoGCaMP fluorescence occurred well before Texas Red entry. On average, half-maximal fluorescence of mitoGCaMP was reached $11 \mathrm{~min}$ before that of Texas Red (14.5 $\pm 2 \mathrm{~min}$ before clearance for mitoGCaMP vs $3.5 \pm 0.4 \mathrm{~min}$ for Texas Red, $n=25$ cells from 8 larvae, mean \pm SEM). Representative behavior of mitoGCaMP relative to Texas Red exclusion can be seen in Figure $10 B$.

Changes in cytoGCaMP fluorescence occurred near the onset of Texas Red entry into dying hair cells, consistent with the temporal separation we observed between $\left[\mathrm{Ca}^{2+}\right]_{\text {mit }}$ and $\left[\mathrm{Ca}^{2+}\right]_{\mathrm{cyt}}$ increases. Half-maximal fluorescence of cytoGCaMP was reached $1 \mathrm{~min}$ before that of Texas Red $(5.7 \pm 0.6 \mathrm{~min}$ before 
A

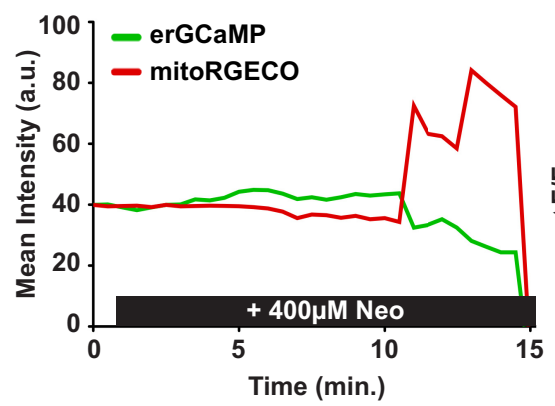

D

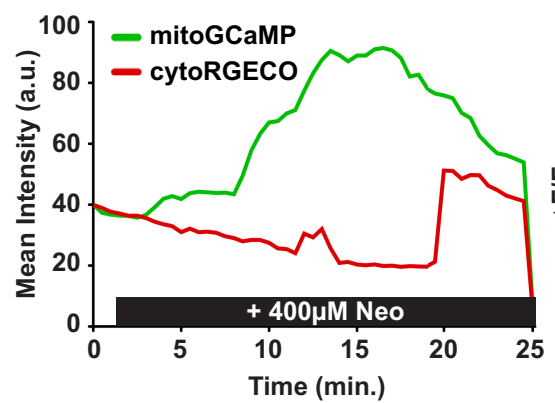

B

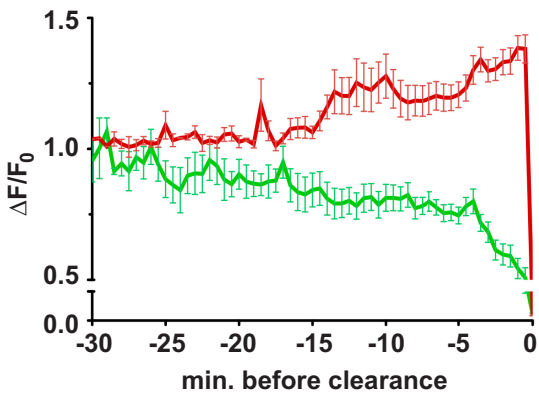

E

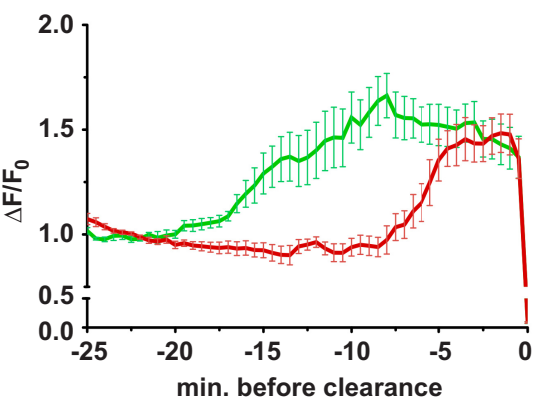

C

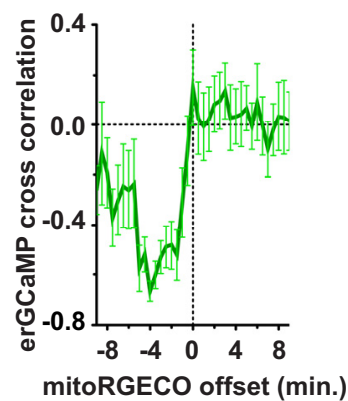

F

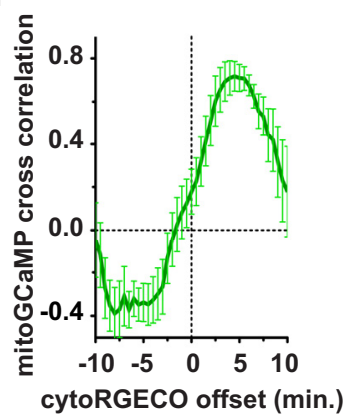

Figure 9. Dual labeling of hair cell compartments confirms organellar $\mathrm{Ca}^{2+}$ flow during aminoglycoside-induced hair cell death. $\boldsymbol{A}, \boldsymbol{D}$, Intensity data of a single anterior lateral line hair cell expressing erGCaMP/mitoRGECO $(\boldsymbol{A})$ or mitoGCaMP/cytoRGECO (D) exposed to $400 \mu$ m neomycin. $\boldsymbol{B}, \boldsymbol{E}$, Mean intensity of erGCaMP/mitoRGEC0 (B) or mitoGCaMP/cytoRGEC0 (E) within dying hair cells exposed to $400 \mu \mathrm{m}$ neomycin aligned to the time at which they are cleared from the neuromast. $\boldsymbol{C}, \boldsymbol{F}$, Mean cross-correlation values of mitoRGECO $(\boldsymbol{C})$ or cytoRGECO $(\boldsymbol{F})$ offset relative to erGCaMP $(\boldsymbol{C})$ or mitoGCaMP $(\boldsymbol{F})$ as GCaMP and RGECO events occur within the same cell. In $\boldsymbol{C}$, maximal $r$ was at 1.5 min, where $r=-0.557 ; p=0.0125$. In $\boldsymbol{E}$, maximal $r$ was at 4.5 min, where $r=0.717 ; p=$ 0.0013. In all grouped data, error bars indicate SEM and $n=15$ from at least 5 animals and 3 experimental runs. See also Movies 3 and 4.

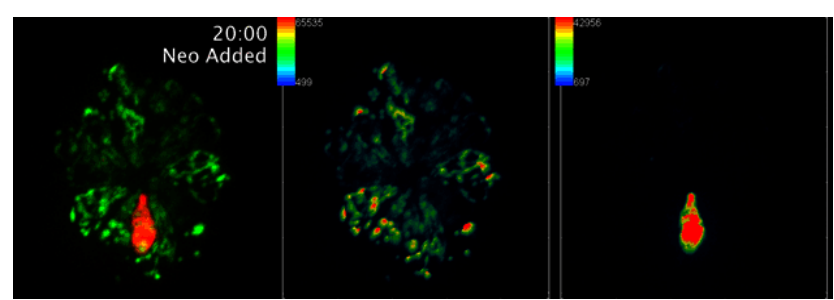

Movie 4. Dynamic changes in mitochondrial $\mathrm{Ca}^{2+}$ relative to cytoplasmic $\mathrm{Ca}^{2+}$ during aminoglycoside-induced hair cell death. Time-lapse movie of a single $\operatorname{Tg}$ (myo6:mitoRGECO) hair cell within a $T g$ (my06:mitoG(aMP3) anterior lateral line neuromast exposed to $400 \mu \mathrm{m}$ neomycin. Left, Pseudocolored mitoGCaMP in green and cytoRGECO in red. Middle, Heat-mapped mitoGCaMP. Right, Heat-mapped cytoRGECO. Time of neomycin addition to embryo medium is indicated (min:sec).

clearance for cytoGCaMP vs $4.5 \pm 0.6 \mathrm{~min}$ for Texas Red, $n=39$ cells from 12 larvae, mean \pm SEM). Representative behavior of cytoGCaMP relative to Texas Red exclusion can be seen in Figure 10C. Together, these data suggest that the initial disruption of intracellular $\mathrm{Ca}^{2+}$ homeostasis occurs before a loss of membrane integrity in dying cells.

\section{$\mathrm{IP}_{3} \mathrm{Rs}$ mediate ER-mitochondrial $\mathrm{Ca}^{2+}$ transfer during} aminoglycoside-induced hair cell death

We next investigated whether disrupting normal regulation of $\mathrm{Ca}^{2+}$ exchange between ER and mitochondria alters aminoglycoside-induced hair cell death. Treatment with thapsigargin increased hair cell death by $\sim 30 \%$ across multiple concentrations of neomycin $(p<0.0001$; Fig. $11 A)$, indicating that potentiating $\left[\mathrm{Ca}^{2+}\right]_{\mathrm{ER}}$ release sensitizes hair cells to aminoglycoside toxicity. Pharmacological manipulation of $\mathrm{IP}_{3} \mathrm{Rs}$ dramati- cally altered neomycin toxicity. Adenophostin A increased hair cell death, whereas xestospongin $\mathrm{C}$ protected hair cells across multiple neomycin concentrations ( $p<0.0001$; Fig. $11 A$ ). Similar protection was observed after blocking mitochondrial $\mathrm{Ca}^{2+}$ entry with Ru360 ( $p<0.0001$; Fig. 11A).

Concurrent exposure of Ru360 and neomycin in hair cells expressing targeted GCaMP allowed us to determine whether uncoupling ER-mitochondrial $\mathrm{Ca}^{2+}$ transfer altered $\mathrm{Ca}^{2+}$ localization as a basis for survival within living cells. As expected, increased mitoGCaMP fluorescence was not observed in living cells cotreated with both neomycin and Ru360 (data not shown). Conversely, fluorescence of cytoGCaMP increased and peaked several times in living cells after neomycin and Ru360 cotreatment, consistent with the notion that Ru360 shunts the flow of $\mathrm{Ca}^{2+}$ leaving the ER into cytoplasm (Fig. 11B). Maximal fluorescence changes of living cells cotreated with Ru360 and $50 \mu \mathrm{M}$ neomycin were $\sim 150 \%$ higher than in living cells exposed to neomycin alone ( $p<0.0001$; Fig. $11 C)$. Cumulative cytoGCaMP fluorescence increased $\sim 60$-fold compared with living cells $(p<$ 0.0001; Fig. 11D). Fluorescence of cytoGCaMP in living cells cotreated with Ru360 and neomycin was not significantly different from that seen in dying cells exposed to neomycin alone (Fig. $11 C, D)$. These data suggest that elevated $\left[\mathrm{Ca}^{2+}\right]_{\mathrm{cyt}}$ alone is not a major contributing factor to aminoglycoside-induced hair cell death. Rather, the efficient transfer of $\mathrm{Ca}^{2+}$ from ER to mitochondria is likely the defining event.

Despite the ability to alter $\mathrm{Ca}^{2+}$ dynamics within cells, ryanodine receptor (RyRs) modulators had no effect on hair cell toxicity either alone or when administered in combination with neomycin (Fig. 12). The contrasting behavior of ER-based $\mathrm{Ca}^{2+}$ release channels in these two scenarios further implicates $\mathrm{IP}_{3}$ recep- 
tors in ER-mitochondrial $\mathrm{Ca}^{2+}$ transfer during aminoglycoside-induced hair cell death.

ER-mitochondrial $\mathrm{Ca}^{2+}$ flow drives mitochondrial activity during aminoglycoside-induced hair cell death Because our observations suggest that mitochondrial activity within hair cells is driven by $\mathrm{Ca}^{2+}$ uptake, we sought to evaluate the timing of $\Delta \psi$ changes relative to ER-mitochondrial $\mathrm{Ca}^{2+}$ transfer after aminoglycoside exposure. We have reported previously that TMRE fluorescence increases and plateaus after aminoglycoside exposure in dying hair cells and that, shortly thereafter, signal is redistributed to the cytoplasm of cells (Esterberg et al., 2013b), consistent with catastrophic MPTP activation (Mitra and Lippincott-Schwartz, 2010; Brand and Nicholls, 2011; Perry et al., 2011). Timing of TMRE redistribution overlaps with the sharp rise in cytoGCaMP fluorescence observed before cell clearance (Esterberg et al., 2013b). We now compare TMRE signals with $\mathrm{ER}$ and mitochondria $\mathrm{Ca}^{2+}$ signals in cells exposed to $400 \mu \mathrm{M}$ neomycin (Fig. 13A for erGCaMP/TMRE; Fig. 13D and Movie 5 for mitoGCaMP/TMRE). To correlate $\mathrm{Ca}^{2+}$ changes to mitochondrial events, we aligned grouped GCaMP data to the cytoplasmic redistribution of TMRE (Fig. 13 B,E). erGCaMP fluorescence decreased before the onset of increased mitochondrial TMRE fluorescence (Fig. 13B), whereas mitoGCaMP fluorescence increase coincided with the onset of increased mitochondrial TMRE fluorescence (Fig. 13E). Cross-correlation of paired data from individual cells revealed strong relationships between erGCaMP or mitoGCaMP and TMRE. erGCaMP was offset $\sim 10-15$ min before TMRE (maximal $r$ for erGCaMP was at 12 min, where $r=-0.708$; $p=0.011$ ) and mitoGCaMP was offset $\sim 1.5-0 \mathrm{~min}$ before TMRE (maximal $r$ was at $1 \mathrm{~min}$, where $r=0.616$; $p=0.0072$; Fig. 13C,F). Paired D1ER/TMRE dynamics revealed a behavior similar to that of erGCaMP/ TMRE (Fig. 14). The timing of these behaviors is consistent with ER-mitochondrial $\mathrm{Ca}^{2+}$ transfer driving increased mitochondrial hyperpolarization during aminoglycoside-induced hair cell death. Further, they suggest that they are at least in part responsible for the catastrophic mitochondrial depolarization that occurs downstream of these events.

\section{Modulation of mitochondrial polarization alters} aminoglycoside toxicity

Given the relationship between mitochondrial $\mathrm{Ca}^{2+}$ overload and catastrophic mPTP activation (Nicholls, 2005, 2009; Giorgi
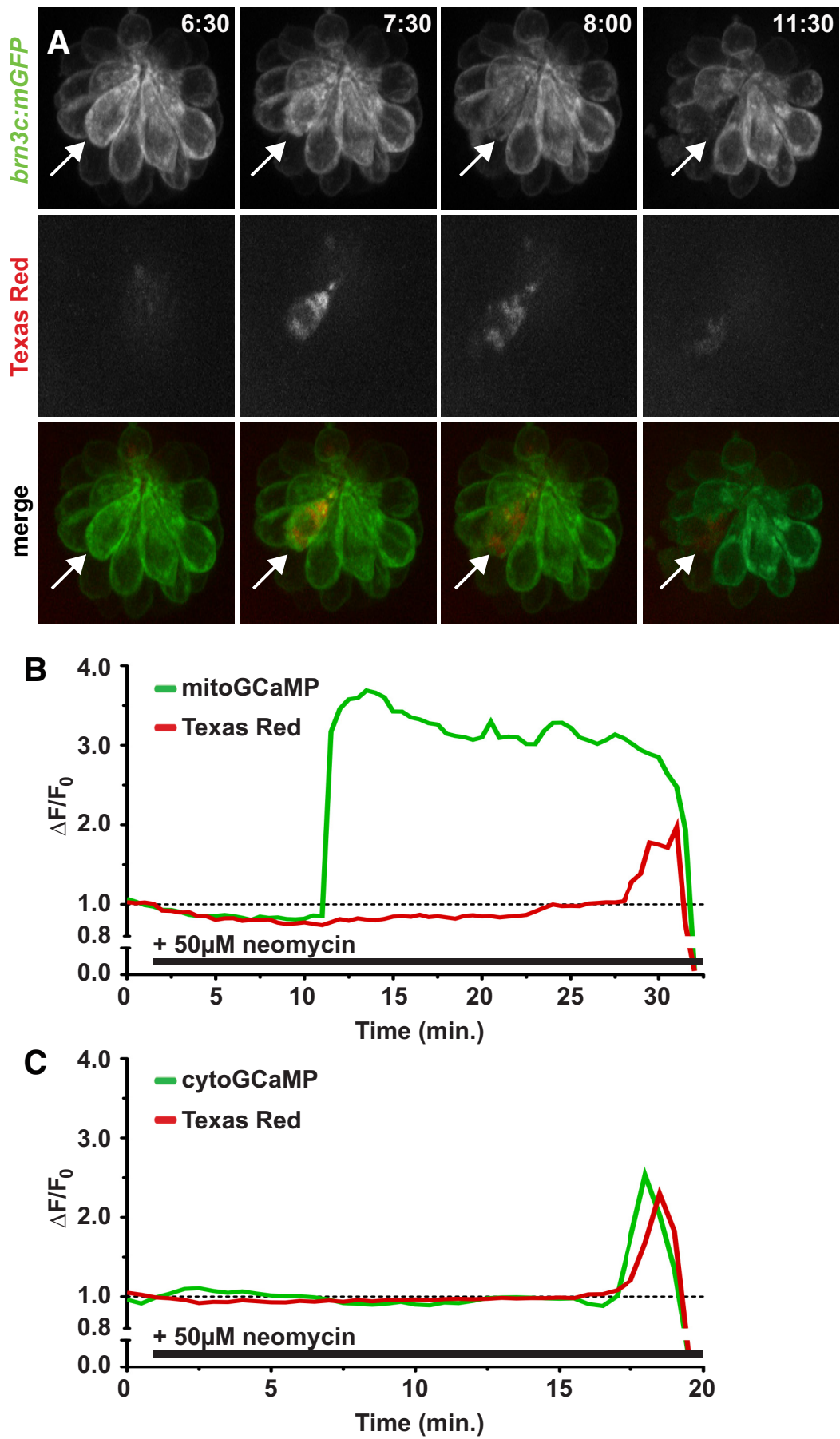

Figure 10. Timing of mitochondrial and cytoplasmic $\mathrm{Ca}^{2+}$ changes relative to Texas Red exclusion in hair cells exposed to neomycin. $\boldsymbol{A}$, Time-lapse images of Texas Red entry in hair cells exposed to $50 \mu \mathrm{m}$ neomycin of $5 \mathrm{dpf} \operatorname{Tg}$ (brn3c:mGFP) larvae. Min:sec after neomycin exposure are indicated. Note the rapid intracellular accumulation of Texas Red within the dying hair cell denoted with the arrow and exclusion from within adjacent hair cells. $B, C$, Transformed $\left(\Delta F / F_{0}\right)$ fluorescence intensity data of Texas Red relative to individual dying mitoGCaMP $(\boldsymbol{B})$ or cytoGCaMP $(\boldsymbol{C})$ cells after exposure to $50 \mu \mathrm{m}$ neomycin.

et al., 2012), we next sought to determine the effects of CsA treatment on aminoglycoside exposure (Fig. 15). Surprisingly, we observed that treatment with CsA sensitized hair cells to the toxic effects of aminoglycosides. Pretreatment with CsA before neomycin exposure increased hair cell death by $\sim 30 \%$ across multiple neomycin concentrations $(p<0.0001$; Fig. 15A). We monitored $\left[\mathrm{Ca}^{2+}\right]_{\text {mit }}$ and $\Delta \psi$ in dying hair cells cotreated with CsA and $50 \mu \mathrm{M}$ neomycin to confirm that CsA was effective at inhibiting $\mathrm{MPTP}$. mitoGCaMP fluorescence was increased in 
A B

B C

C
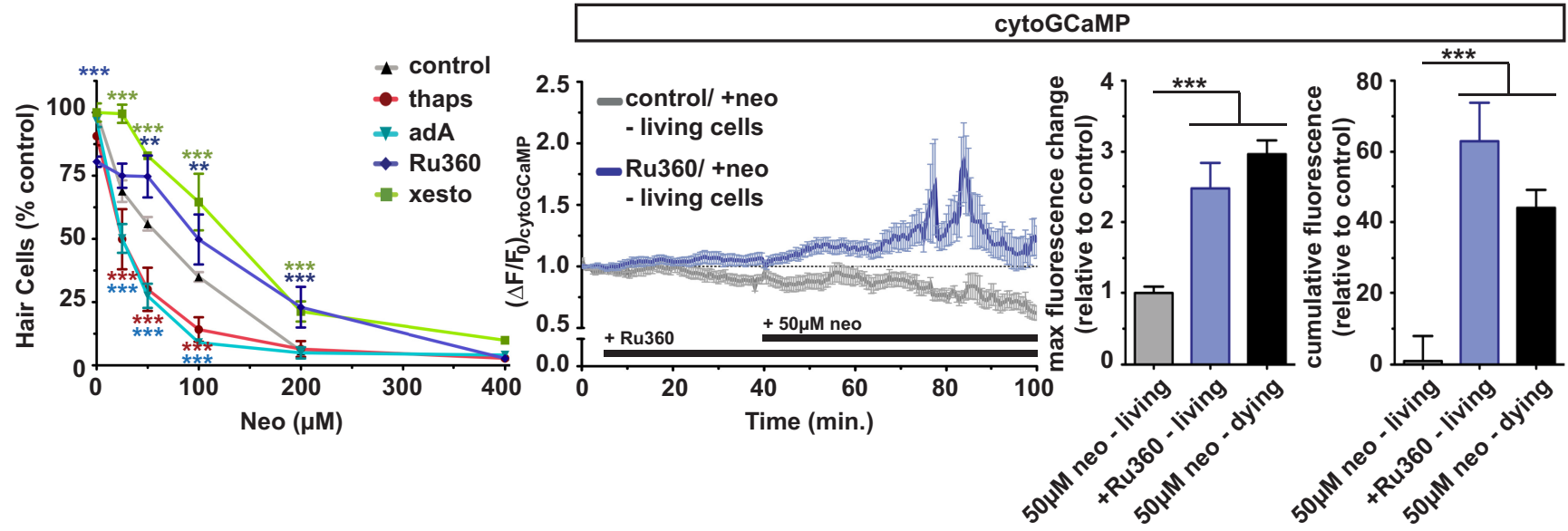

D

Figure 11. Pharmacological manipulation of $\mathbb{P}_{3}$-based ER-mitochondrial $\mathrm{Ca}^{2+}$ transfer alters aminoglycoside toxicity. $\boldsymbol{A}$, Pharmacological disruption of ER-based SERCA pumps or MAM channels alters the response of lateral line hair cells to neomycin. Inhibition of ER-based SERCA pumps with thapsigargin or stimulation of ER Ca ${ }^{2+}$ efflux at IP $\mathrm{P}_{3} \mathrm{Rs}$ with adenophostin A sensitizes hair cells to the toxic effects of neomycin. Inhibition of $\mathrm{IP}_{3} \mathrm{Rs}$ with xestospongin ( or of mitochondrial uniporter channels with Ru360, which lie in apposition to each other at MAM junctions, protects hair cells against the toxic effects of neomycin. $\boldsymbol{B}-\boldsymbol{D}$, Inhibition of mitochondrial $\mathrm{Ca}^{2+}$ uptake with Ru360 shunts ER-derived $\mathrm{Ca}^{2+}$ into the cytoplasm of rescued cells. $\boldsymbol{B}$, Mean transformed $\left(\Delta F / F_{0}\right)$ fluorescence intensity values of cytoGCaMP anterior lateral line hair cells exposed first to Ru360 and then to $50 \mu$ m neomycin. $\boldsymbol{C}, \boldsymbol{D}$, Maximal (C) or cumulative (D) cytoGCaMP fluorescence in living and dying cells exposed to $50 \mu \mathrm{m}$ neomycin alone or first exposed to Ru360 and then $50 \mu \mathrm{m}$ neomycin. In $A$, hair cell counts are of parvalbumin-positive hair cells and error bars indicate SD; $n=6$ neuromasts from each of 5 treated animals. Two-way ANOVA, Tukey post test ${ }^{* * *} p<0.0001 ;{ }^{* *} p<0.01$. In $\boldsymbol{B}-\boldsymbol{D}$, error bars indicate SEM and $n=1250 \mu \mathrm{m} \mathrm{ne0-living}, n=2150 \mu \mathrm{m}$ neo- dying, and $n=1350 \mu$ m neo + Ru360 -living cells from at least 5 animals. One-way ANOVA, Dunnett post test ${ }^{* *} p<0.0001$.

A

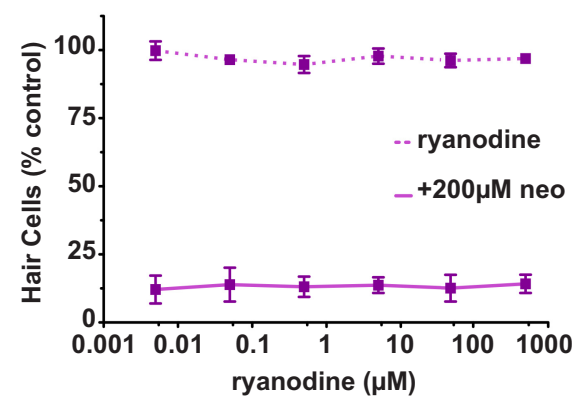

C

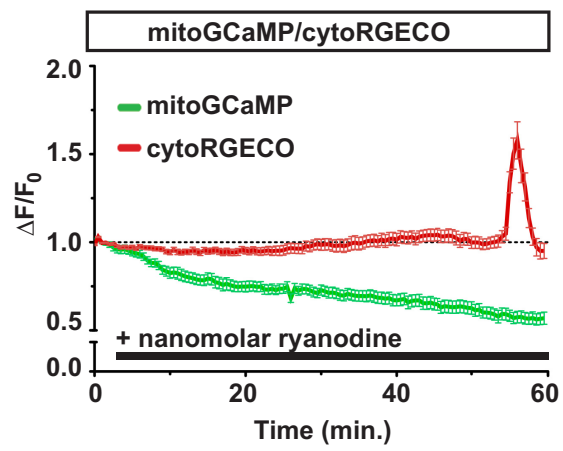

B

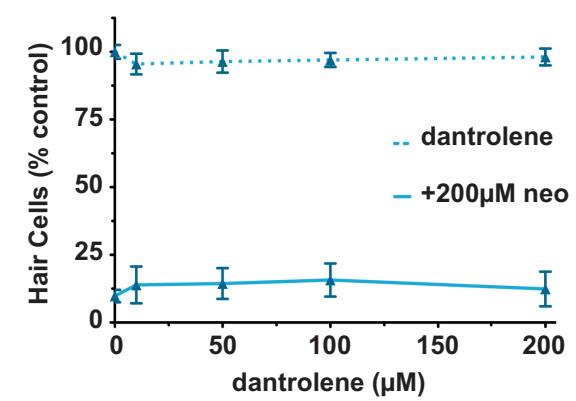

D

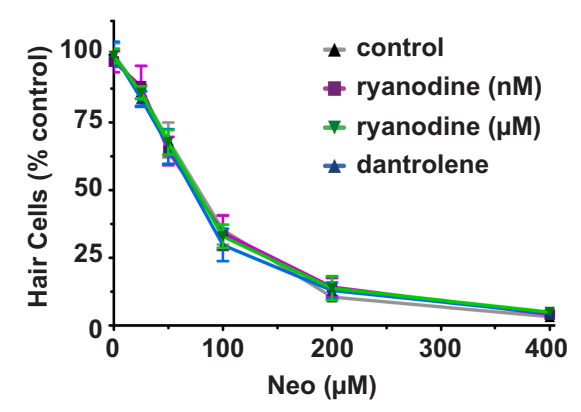

Figure 12. Modulation of RyRs does not alter aminoglycoside toxicity. $A, B$, Determination of optimal concentrations of ryanodyne $(\boldsymbol{A})$ and dantrolene $(\boldsymbol{B})$ after pretreatment and coexposure in embryo medium alone (solid line) or containing $200 \mu \mathrm{m}$ neomycin (dashed line). C, Ryanodine modulation elicits an intracellular $\mathrm{Ca}^{2+}$ response under physiological conditions. Mean transformed $\left(\Delta F / F_{0}\right)$ mitoGCaMP/cytoRGECO fluorescence intensity values of anterior lateral line hair cells exposed to $50 \mathrm{~nm}$ Ryanodyne. D, Pharmacological modulation of ER-based RyRs either with the RyR antagonist dantrolene or multiple concentrations of ryanodyne has no effect on neomycin toxicity. Micromolar levels of ryanodyne $(500 \mu \mathrm{m})$ were used to inhibit RyRs and nanomolar levels of ryanodyne (50 nM) were used to stimulate RyR activity. Hair cell counts are of parvalbumin-positive hair cells. In $A, B$, and $\boldsymbol{D}$, error bars indicate SD and $n=6$ neuromasts from each of 5 treated animals. In $\boldsymbol{C}$, error bars indicate SEM and $n=19$ cells from at least 5 animals. $\ln \boldsymbol{D}$, two-way ANOVA, Tukey post test ${ }^{* * *} p<0.0001 ;{ }^{* *} p<0.01$. these cells compared with neomycin alone (Fig. 15B) and cumulative fluorescence was $\sim 100 \%$ higher than in dying cells exposed to neomycin alone $(p<0.0001$; Fig. 15C). Maximal TMRE fluorescence was also increased, reaching levels 100\% greater than cells exposed to neomycin alone ( $p<0.0001$; Fig. $15 D)$.

In contrast to the results using CsA, levels of FCCP capable of partial mitochondrial depolarization (Fig. 3; Bernardi, 1992; Petronilli et al., 1993) protect hair cells across multiple neomycin concentrations $(p<0.0001$; Fig. 15A) and prevent mitochondrial $\mathrm{Ca}^{2+}$ uptake and hyperpolarization after neomycin exposure (data not shown). Together, these results suggest that transient mitochondrial depolarization adjusts levels of $\left[\mathrm{Ca}^{2+}\right]_{\mathrm{mit}}$ and $\Delta \psi$ and that this regulation is essential to hair cell survival after aminoglycoside exposure.

\section{Discussion}

The tight regulation of $\mathrm{Ca}^{2+}$ maintained within subcellular compartments is a key determinant of cell function and survival. This is particularly true in the ER, where $\left[\mathrm{Ca}^{2+}\right]$ is at its highest and depletion induces susceptibility to apoptogens (Chami et al., 2008; Giorgi et al., 2010). Such observations appear to translate to hair cells. Mutations in genes involved in regulation of $\left[\mathrm{Ca}^{2+}\right]_{\mathrm{ER}}$ have been implicated in several types of heritable hearing loss (Osman et al., 2003; Takei et al., 2006; Wortmann et al., 2012; Wiley et al., 2013). 
A

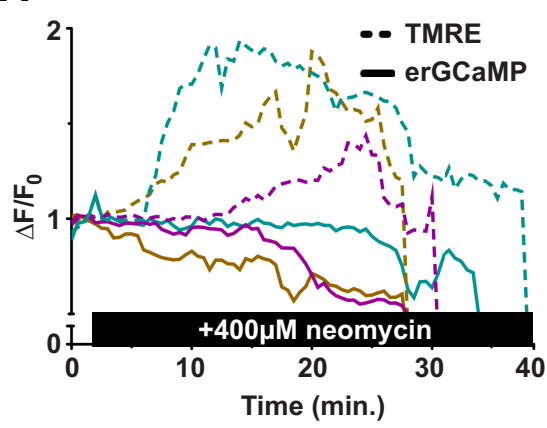

B

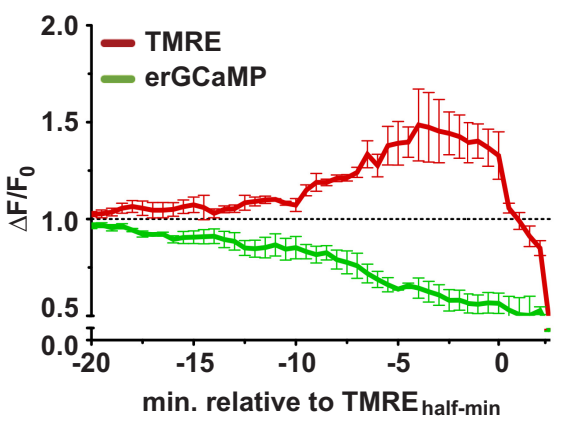

C

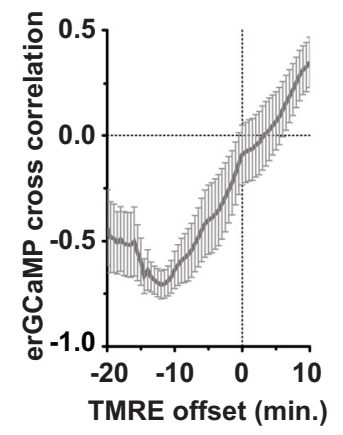

D

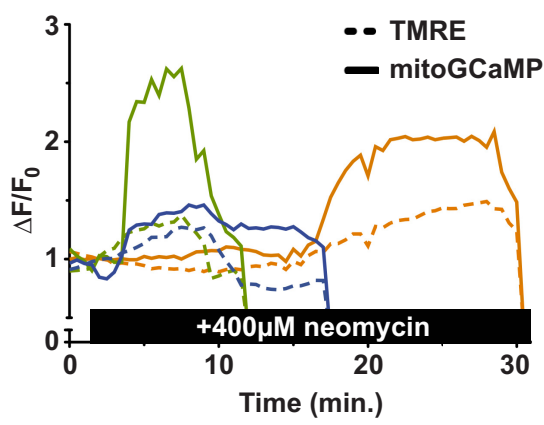

E

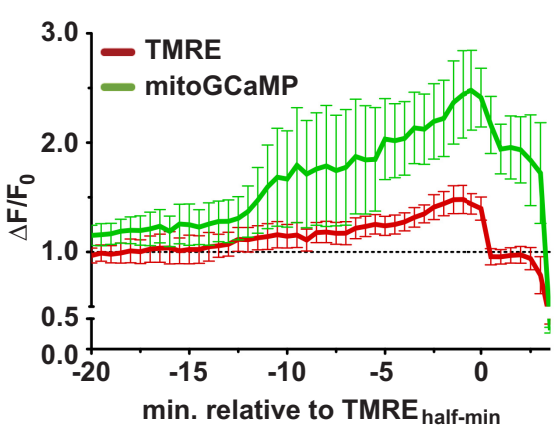

F

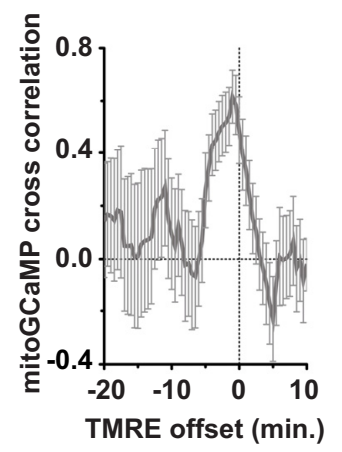

Figure 13. Timing of organellar $\mathrm{Ca}^{2+}$ mobilization relative to mitochondrial hyperpolarization. $\boldsymbol{A}, \boldsymbol{D}$, Individual intensities of erGCaMP $(\boldsymbol{A})$ or mitoGCaMP $(\boldsymbol{D})$ in dying anterior lateral line hair cells colabeled with TMRE and exposed to $400 \mu$ m neomycin. $\boldsymbol{B}, \boldsymbol{E}$, Mean intensity of erGCaMP $(\boldsymbol{B})$ or mitoGCaMP $(\boldsymbol{E})$ in dying anterior lateral line hair cells colabeled with TMRE and exposed to $400 \mu \mathrm{M}$ neomycin. Data were aligned to TMRE ${ }_{\text {half-min' }}$ corresponding to TMRE redistribution from mitochondria into cytoplasm. $\boldsymbol{C}, \boldsymbol{F}$, Mean cross-correlation values of TMRE offset relative to erGCaMP $(\boldsymbol{C})$ or mitoGCaMP $(\boldsymbol{F})$ as TMRE and $\mathrm{Ca}^{2+}$ sensor dynamics occur within the same cell. In $\boldsymbol{C}$, maximal $r$ for erGCaMP was at 12 min, where $r=-0.708$ and $p=0.011$. In $\boldsymbol{F}$, maximal $r$ was at 1 min, where $r=0.616$ and $p=0.0072$. Error bars indicate SEM and $n=10$ erGCaMP/TMRE and $n=15$ mitoGCaMP/TMRE from at least 5 animals and 3 experimental runs. See also Movie 5 .

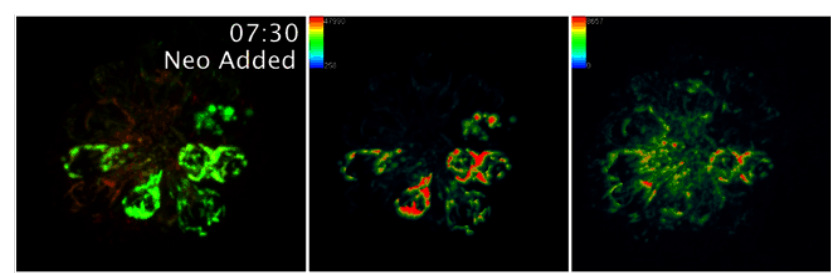

Movie 5. Changes in mitochondrial $\mathrm{Ca}^{2+}$ relative to membrane potential during aminoglycoside-induced hair cell death. Time-lapse movie of a $\operatorname{Tg}$ (myo6:mitoG(aMP3) anterior lateral line neuromast colabeled with TMRE and exposed to $50 \mu \mathrm{m}$ neomycin. Left, Pseudocolored mitoGCaMP in green and TMRE in red. Middle, Heat-mapped mitoGCaMP. Right, Heatmapped TMRE.

The dynamics of multiple subcellular events presented here support a model in which changes in $\left[\mathrm{Ca}^{2+}\right]_{\text {mit }}$ and $\left[\mathrm{Ca}^{2+}\right]_{\mathrm{cyt}}$ after aminoglycoside exposure originate with the disruption of $\mathrm{Ca}^{2+}$ homeostasis within the ER (Fig. 16). Although the exact mechanisms of this disruption is unclear, aminoglycoside antibiotics have been shown to interact with calreticulin, the predominant $\mathrm{Ca}^{2+}$-binding protein of the $\mathrm{ER}$, at its $\mathrm{Ca}^{2+}$-binding domain (Karasawa et al., 2011). It is plausible to hypothesize that this interaction impedes $\mathrm{Ca}^{2+}$ binding and initiates $\mathrm{Ca}^{2+}$ efflux from the ER.

In cultured cells, MAMs appear to be inefficient at transferring $\mathrm{Ca}^{2+}$ between ER and mitochondria (Hajnóczky et al., 1995; Csordás et al., 1999; Szalai et al., 1999; Hajnóczky et al., 2000; Pacher et al., 2000; Csordás et al., 2002) and it has remained an ongoing question as to how much $\mathrm{Ca}^{2+}$ exiting the ER first transits the cytoplasm before mitochondrial uptake occurs (Giorgi et al., 2009; Rizzuto et al., 2009). Here, we report that, in hair cells, in vivo aminoglycoside-initiated flow involves little or no detectable release into cytoplasm before a large increase in the mitochondria. One counter argument is that the sensitivities of our cytoplasmic indicators are insufficient to detect short-lived changes in $\left[\mathrm{Ca}^{2+}\right]_{\text {cyt }}$ localized at microdomains. However, we have shown previously that our cytoplasmic GCaMP3 construct undergoes detectable fluorescence increases in the presence of just $70 \mathrm{~nm}$ extracellular $\mathrm{Ca}^{2+}$ and ionomycin, yet we observe little fluctuation in signal until shortly before cell clearance (Esterberg et al., 2013b). Furthermore, we are capable of detecting synchronous increases in cytoRGECO and mitoGCaMP when IP3Rs are stimulated with AdA, yet detect much smaller cytoRGECO increases around the time of mitoGCaMP increases after neomycin exposure. We believe that these observations, coupled with the data presented here, suggest that the aminoglycoside-induced change in efficiency at which $\mathrm{Ca}^{2+}$ is transferred between ER and mitochondria underlies the sensitivity of hair cells to ototoxic therapeutics; after mobilization of $\mathrm{Ca}^{2+}$ from the ER during aminoglycoside-induced hair cell death, there appears to be facilitation of the path for $\mathrm{Ca}^{2+}$ to enter mitochondria.

The strength of association between ER and mitochondria, and thus the efficiency of $\mathrm{Ca}^{2+}$ transfer through MAMs, is regulated in part by bioenergetic status within the cell (Cárdenas et al., 2010; Bravo et al., 2011; Gomes et al., 2011). ER stress caused by $\mathrm{Ca}^{2+}$ efflux both strengthens existing MAM connections and forms nascent ones (Chami et al., 2008), promoting additional $\mathrm{Ca}^{2+}$ transfer from the ER. One possible reason for such efficient transfer in hair cells is the high metabolic load under which they operate. Metabolic compromise underlies a significant portion of 
A

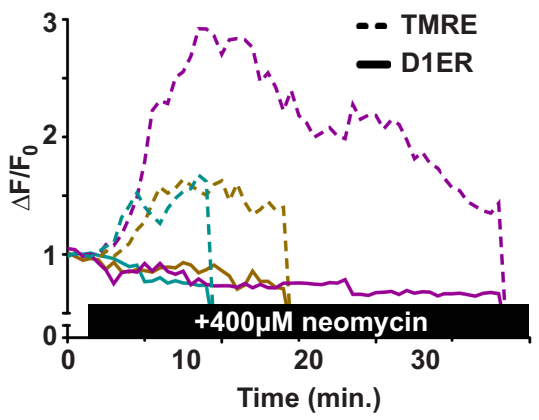

B

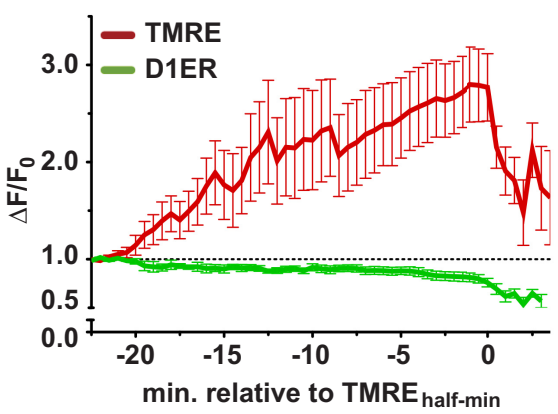

C

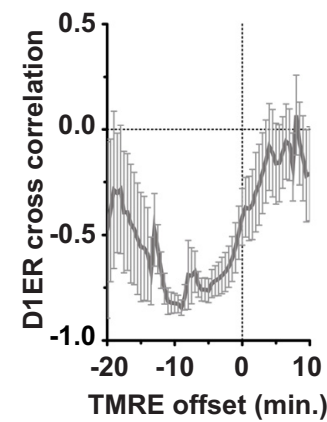

Figure 14. Timing of D1ER fluorescence changes relative to mitochondrial hyperpolarization. $\boldsymbol{A}$, Individual intensity of D1ER in dying anterior lateral line hair cells colabeled with TMRE and exposed to $400 \mu \mathrm{m}$ neomycin. $\boldsymbol{B}$, Mean D1ER intensity in dying anterior lateral line hair cells colabeled with TMRE and exposed to $400 \mu \mathrm{m}$ neomycin. Data were aligned to TMRE ${ }_{\mathrm{half}-\mathrm{min}^{\prime}}$ corresponding to TMRE redistribution from mitochondria into cytoplasm. C, Mean cross-correlation values of TMRE offset relative to D1ER as TMRE and Ca ${ }^{2+}$ sensor dynamics occur within the same cell. Maximal $r$ for D1ER was at $9 \mathrm{~min}$, where $r=-0.85$ and $p=0.002$. Error bars indicate SEM and $n=12$ from at least 5 animals and 3 experimental runs.

A

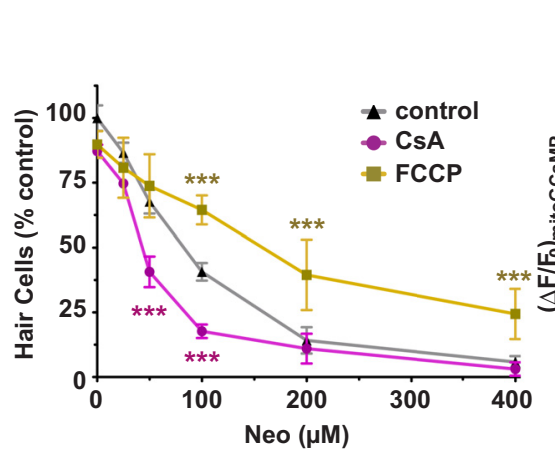

B

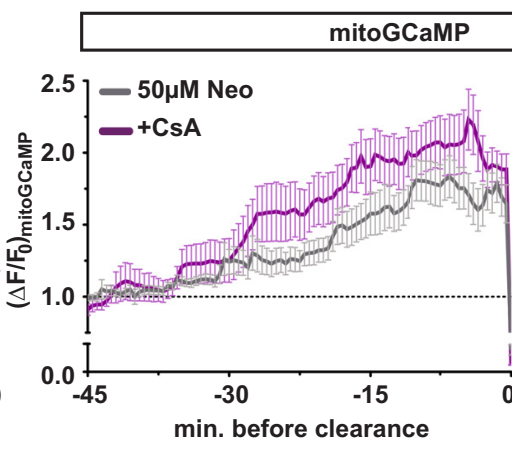

C

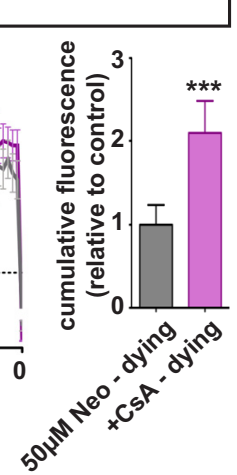

D

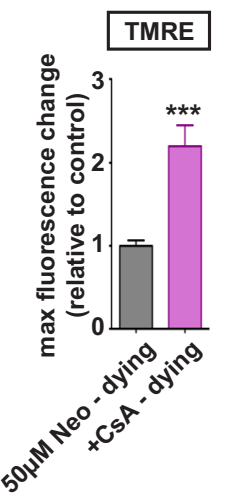

Figure 15. Mitochondrial hyperpolarization increases mitochondrial $\mathrm{Ca}^{2+}$ accumulation and its related effects and sensitizes hair cells to the toxic effects of aminoglycosides. $A$, Pharmacological modulation of the mPTP alters the response of lateral line hair cells to neomycin. Treatment with CsA sensitizes hair cells to the toxic effects of neomycin. Partial depolarization with sublethal concentrations of $\mathrm{FCCP}(300 \mathrm{pM})$ protects hair cells against the toxic effects of neomycin. $\boldsymbol{B}$, Mean transformed $\left(\Delta F / F_{0}\right)$ mitoGCaMP fluorescence intensity values in dying anterior lateral line hair cells exposed to either CSA and $50 \mu \mathrm{m}$ neomycin or $50 \mu \mathrm{m}$ neomycin alone. C, Cumulative mitoGCaMP fluorescence in dying cells exposed to $50 \mu \mathrm{m}$ neomycin alone or first exposed to CsA and then $50 \mu \mathrm{m}$ neomycin. $\boldsymbol{D}$, Maximal change in TMRE fluorescence in dying cells exposed to $50 \mu \mathrm{m}$ neomycin alone or first exposed to CSA and then $50 \mu \mathrm{m}$ neomycin. In $A$, error bars indicate SD and $n=6$ neuromasts from each of 5 treated animals. Two-way ANOVA, Tukey post test ${ }^{* * *} p<0.0001$. In $\boldsymbol{B}-\boldsymbol{D}$, error bars indicate SEM and $n=12$ cells each. Cells are from at least 3 animals and 3 experimental runs. One-way ANOVA, Dunnett post test ${ }^{* * *} p<0.0001$.

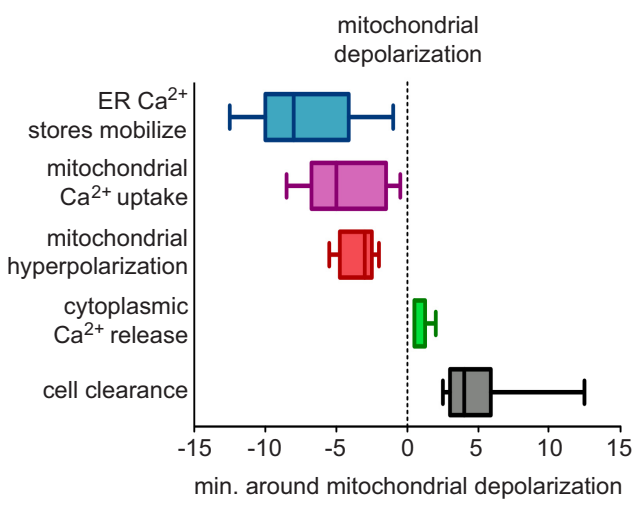

Figure 16. Timing of subcellular events monitored here during aminoglycoside-induced hair cell death. Box-and-whisker plot of the time at which half-maximal change in fluorescence of each indicator is reached relative to TMRE ${ }_{\text {half-min' }}$ corresponding to TMRE redistribution from mitochondria into cytoplasm. Error bars indicate minimal and maximal values. Middle bar indicates the mean. nonsyndromic hearing loss (Fischel-Ghodsian, 1999; Shadel, 2004; Bindu and Reddy, 2008) and aminoglycoside susceptibility (Hobbie et al., 2008). Therefore, the fine tuning of $\mathrm{Ca}^{2+}$ transfer between ER and mitochondria effectively balances life or death responses and appears to be a tipping point during aminoglycoside-induced hair cell death.

Although low levels of mitochondrial $\mathrm{Ca}^{2+}$ uptake feeds energetically active cells through ATP production, prolonged uptake can be toxic as it overloads mitochondria, in part through catastrophic activation of the MPTP. This event permanently disrupts the electron transport chain and initiates proteolytic events related to increased ROS production and cytochrome $c$ release (Nicholls, 2005; Giorgi et al., 2008; Giorgi et al., 2012). It is therefore no surprise that many studies focus on this event as a strategy to prevent cell death. Indeed, inhibition of MPTP activation delays mitochondrial overload and increases survival in models of excitotoxicity and stroke (Crompton et al., 1988; Schinder et al., 1996; Stout et al., 1998; Matsumoto et al., 1999; Vergun et al., 1999; Brustovetsky and Dubinsky, 2000; Baines et al., 2005; Nakagawa et al., 2005; Schinzel et al., 2005; Bambrick et al., 2006; 
Piot et al., 2008; Li et al., 2009). Our results indicate that this strategy may not be effective to stave hearing loss resulting from ototoxicity because they implicate transient mPTP activation in the gating of excess $\left[\mathrm{Ca}^{2+}\right]_{\text {mit }}$ and $\Delta \psi$. More globally, disruption of tight regulation of ER-mitochondrial $\mathrm{Ca}^{2+}$ flow and its downstream mitochondrial effects may present a common mechanism underlying cytotoxicity of aminoglycoside antibiotics; aminoglycoside sensitive renal tubule cells are also sensitive to CsA alone (Busauschina et al., 2004; Chapman and Nankivell, 2006) and a synergistic increase in toxicity is revealed when CsA and aminoglycosides are administered in concert (Lane et al., 1977; Oliveira et al., 2009).

CsA is a general inhibitor of cyclophilins, of which cyclophilin $\mathrm{D}$ is the only family member that acts as an important but dispensable regulator of the MPTP. Inhibition is variable (Hansson et al., 2003; Kobayashi et al., 2003), raising the possibility that modulation of other mPTP components produce a fundamentally different mitochondrial response when exposed to aminoglycosides. We found that CsA does not protect against catastrophic mitochondrial depolarization. This may be because the doses of CsA that we used were sufficient to block transient opening of the mPTP but insufficient to prevent the final catastrophic mPTP opening, resulting in mitochondrial collapse. It should be noted, however, that we do not know definitively whether the final collapse in potential is the direct result of such a catastrophic MPTP opening event. Despite this caveat, sustained elevation of TMRE and mitoGCaMP fluorescence during aminoglycoside-induced hair cell death is evidence of mitochondrial inability to relieve itself of elevated $\left[\mathrm{Ca}^{2+}\right]_{\text {mit }}$ and $\Delta \psi$ and suggests that mitochondrial function is impaired well before collapse of mitochondrial potential. Our findings seem to align with those of several groups that have used CsA to study transient mPTP activation (Ichas et al., 1997; Smaili and Russell, 1999; Wang et al., 2008; Korge et al., 2011; Ma et al., 2011; Wang et al., 2012).

Our results join a small but growing body of literature (Stout et al., 1998; Maragos et al., 2003; Mattiasson et al., 2003; Jin et al., 2004; Brennan et al., 2006a; Brennan et al., 2006b; Pandya et al., 2007) suggesting that the best way to prevent mitochondrial overload is to prevent excessive $\mathrm{Ca}^{2+}$ uptake altogether through partial depolarization. Several interrelated mechanisms are likely responsible for the protective effects observed here during aminoglycoside exposure, originating with the cross-regulation of $\Delta \psi$ and mitochondrial $\mathrm{Ca}^{2+}$ uptake. $\Delta \psi$ is the driving force behind mitochondrial uniporter activity and therefore $\mathrm{Ca}^{2+}$ uptake (Gunter and Pfeiffer, 1990; Gunter et al., 1994; White and Reynolds, 1997; Stout et al., 1998), which can in turn drive an increase in $\Delta \psi$ if not properly regulated by transient opening of the MPTP (Brookes et al., 2004; Nicholls, 2005).

Although the data presented here are consistent with a disruption of ER- mitochondria $\mathrm{Ca}^{2+}$ flow, they do not exclude the possibility that $\mathrm{Ca}^{2+}$ from other sources contribute to the behaviors we have observed. Because aminoglycosides induce membrane reorganization even at sublethal exposures (Goodyear et al., 2008), perhaps the most likely alternative source of $\mathrm{Ca}^{2+}$ originates from outside of the cell. Because we observed increases in mitoGCaMP fluorescence before Texas Red entry into dying hair cells, we believe that it is reasonable to conclude that extracellular $\mathrm{Ca}^{2+}$ plays little role in the mitochondrial dynamics observed in dying hair cells. It is, however, more difficult to pinpoint the contribution of extracellular $\mathrm{Ca}^{2+}$ to the increase in $\left[\mathrm{Ca}^{2+}\right]_{\text {cyt }}$. Although we have demonstrated that the rise in $\left[\mathrm{Ca}^{2+}\right]_{\mathrm{cyt}}$ overlaps with catastrophic loss of mitochondrial po- tential and posited mitochondria as the primary source of this cytosolic increase (Esterberg et al., 2013b), it seems likely that extracellular $\mathrm{Ca}^{2+}$ contributes at least in part to the elevation in $\left[\mathrm{Ca}^{2+}\right]_{\text {cyt }}$ that occurs just before cell clearance.

The inability of mitochondria to gate excess $\left[\mathrm{Ca}^{2+}\right]_{\text {mit }}$ effectively may be due to the sheer volume of $\mathrm{Ca}^{2+}$ transferred from the ER as a result of the tight linkage between ER and mitochondrial $\mathrm{Ca}^{2+}$ channels. It stands to reason, then, that less efficient transfer between ER and mitochondria offer a cytoprotective benefit after aminoglycoside exposure. Indeed, Ru360 protects hair cells against the toxic effects of aminoglycosides and shunts ER-derived $\mathrm{Ca}^{2+}$ into cytoplasm (Fig. 11). We cannot rule out the possibility that transient increases in cytoplasmic $\mathrm{Ca}^{2+}$ that we observed affected the cell in some way, because other processes are encoded in the dynamic behavior of cytoplasmic $\mathrm{Ca}^{2+}$ (Carafoli et al., 2001; Clapham, 2007). Nonetheless, our results indicate that high levels of cytoplasmic $\mathrm{Ca}^{2+}$ are better tolerated than previously thought, drawing into focus the delicate balance of $\mathrm{Ca}^{2+}$ flow between ER and mitochondria.

\section{References}

Alharazneh A, Luk L, Huth M, Monfared A, Steyger PS, Cheng AG, Ricci AJ (2011) Functional hair cell mechanotransducer channels are required for aminoglycoside ototoxicity. PLoS One 6:e22347. CrossRef Medline

Baines CP, Kaiser RA, Purcell NH, Blair NS, Osinska H, Hambleton MA, Brunskill EW, Sayen MR, Gottlieb RA, Dorn GW, Robbins J, Molkentin JD (2005) Loss of cyclophilin D reveals a critical role for mitochondrial permeability transition in cell death. Nature 434:658-662. CrossRef Medline

Bambrick LL, Chandrasekaran K, Mehrabian Z, Wright C, Krueger BK, Fiskum G (2006) Cyclosporin A increases mitochondrial calcium uptake capacity in cortical astrocytes but not cerebellar granule neurons. J Bioenerg Biomembr 38:43-47. CrossRef Medline

Bernardi P (1992) Modulation of the mitochondrial cyclosporin A-sensitive permeability transition pore by the proton electrochemical gradient. Evidence that the pore can be opened by membrane depolarization. J Biol Chem 267:8834-8839. Medline

Bindu LH, Reddy PP (2008) Genetics of aminoglycoside-induced and prelingual non-syndromic mitochondrial hearing impairment: a review. Int J Audiol 47:702-707. CrossRef Medline

Bononi A, Missiroli S, Poletti F, Suski JM, Agnoletto C, Bonora M, De Marchi E, Giorgi C, Marchi S, Patergnani S, Rimessi A, Wieckowski MR, Pinton P (2012) Mitochondria-associated membranes (MAMs) as hotspot $\mathrm{Ca}(2+)$ signaling units. Adv Exp Med Biol 740:411-437. CrossRef Medline

Brand MD, Nicholls DG (2011) Assessing mitochondrial dysfunction in cells. Biochem J 435:297-312. CrossRef Medline

Bravo R, Vicencio JM, Parra V, Troncoso R, Munoz JP, Bui M, Quiroga C, Rodriguez AE, Verdejo HE, Ferreira J, Iglewski M, Chiong M, Simmen T, Zorzano A, Hill JA, Rothermel BA, Szabadkai G, Lavandero S (2011) Increased ER-mitochondrial coupling promotes mitochondrial respiration and bioenergetics during early phases of ER stress. J Cell Sci 124: 2143-2152. CrossRef Medline

Bravo R, Gutierrez T, Paredes F, Gatica D, Rodriguez AE, Pedrozo Z, Chiong M, Parra V, Quest AF, Rothermel BA, Lavandero S (2012) Endoplasmic reticulum: ER stress regulates mitochondrial bioenergetics. Int J Biochem Cell Biol 44:16-20. CrossRef Medline

Brennan JP, Berry RG, Baghai M, Duchen MR, Shattock MJ (2006a) FCCP is cardioprotective at concentrations that cause mitochondrial oxidation without detectable depolarisation. Cardiovasc Res 72:322-330. CrossRef Medline

Brennan JP, Southworth R, Medina RA, Davidson SM, Duchen MR, Shattock MJ (2006b) Mitochondrial uncoupling, with low concentration FCCP, induces ROS-dependent cardioprotection independent of KATP channel activation. Cardiovasc Res 72:313-321. CrossRef Medline

Brookes PS, Yoon Y, Robotham JL, Anders MW, Sheu SS (2004) Calcium, ATP, and ROS: a mitochondrial love-hate triangle. Am J Physiol Cell Physiol 287:C817-C833. CrossRef Medline

Brustovetsky N, Dubinsky JM (2000) Limitations of cyclosporin A inhibi- 
tion of the permeability transition in CNS mitochondria. J Neurosci 20: 8229-8237. Medline

Busauschina A, Schnuelle P, van der Woude FJ (2004) Cyclosporine nephrotoxicity. Transplant Proc 36:229S-233S. CrossRef Medline

Carafoli E, Santella L, Branca D, Brini M (2001) Generation, control, and processing of cellular calcium signals. Crit Rev Biochem Mol Biol 36:107260. CrossRef Medline

Cárdenas C, Miller RA, Smith I, Bui T, Molgó J, Müller M, Vais H, Cheung KH, Yang J, Parker I, Thompson CB, Birnbaum MJ, Hallows KR, Foskett JK (2010) Essential regulation of cell bioenergetics by constitutive InsP3 receptor $\mathrm{Ca} 2+$ transfer to mitochondria. Cell 142:270-283. CrossRef Medline

Chami M, Oulès B, Szabadkai G, Tacine R, Rizzuto R, Paterlini-Bréchot P (2008) Role of SERCA1 truncated isoform in the proapoptotic calcium transfer from ER to mitochondria during ER stress. Mol Cell 32:641-651. CrossRef Medline

Chapman JR, Nankivell BJ (2006) Nephrotoxicity of ciclosporin A: shortterm gain, long-term pain? Nephrol Dial Transplant 21:2060-2063. CrossRef Medline

Chiu LL, Cunningham LL, Raible DW, Rubel EW, Ou HC (2008) Using the zebrafish lateral line to screen for ototoxicity. J Assoc Res Otolaryngol 9:178-190. CrossRef Medline

Clapham DE (2007) Calcium signaling. Cell 131:1047-1058. CrossRef Medline

Crompton M, Ellinger H, Costi A (1988) Inhibition by cyclosporin A of a $\mathrm{Ca} 2+$-dependent pore in heart mitochondria activated by inorganic phosphate and oxidative stress. Biochem J 255:357-360. Medline

Csordás G, Thomas AP, Hajnóczky G (1999) Quasi-synaptic calcium signal transmission between endoplasmic reticulum and mitochondria. EMBO J 18:96-108. CrossRef Medline

Csordás G, Madesh M, Antonsson B, Hajnóczky G (2002) tcBid promotes $\mathrm{Ca}(2+)$ signal propagation to the mitochondria: control of $\mathrm{Ca}(2+)$ permeation through the outer mitochondrial membrane. EMBO J 21:21982206. CrossRef Medline

Dehne N, Rauen U, de Groot H, Lautermann J (2002) Involvement of the mitochondrial permeability transition in gentamicin ototoxicity. Hear Res 169:47-55. CrossRef Medline

Duchen MR, Leyssens A, Crompton M (1998) Transient mitochondrial depolarizations reflect focal sarcoplasmic reticular calcium release in single rat cardiomyocytes. J Cell Biol 142:975-988. CrossRef Medline

Ellis-Davies GC, Kaplan JH, Barsotti RJ (1996) Laser photolysis of caged calcium: rates of calcium release by nitrophenyl-EGTA and DMnitrophen. Biophys J 70:1006-1016. CrossRef Medline

Esterberg R, Coffin AB, Ou H, Simon JA, Raible DW, and Rubel EW (2013a) Fish in a dish: drug discovery for hearing habilitation. Drug Discov Today Dis Models 10.

Esterberg R, Hailey DW, Coffin AB, Raible DW, Rubel EW (2013b) Disruption of intracellular calcium regulation is integral to aminoglycosideinduced hair cell death. J Neurosci 33:7513-7525. CrossRef Medline

Fischel-Ghodsian N (1999) Mitochondrial deafness mutations reviewed. Hum Mutat 13:261-270. CrossRef Medline

Gafni J, Munsch JA, Lam TH, Catlin MC, Costa LG, Molinski TF, Pessah IN (1997) Xestospongins: potent membrane permeable blockers of the inositol 1,4,5-trisphosphate receptor. Neuron 19:723-733. CrossRef Medline

Giorgi C, Romagnoli A, Pinton P, Rizzuto R (2008) Ca2 + signaling, mitochondria and cell death. Curr Mol Med 8:119-130. CrossRef Medline

Giorgi C, De Stefani D, Bononi A, Rizzuto R, Pinton P (2009) Structural and functional link between the mitochondrial network and the endoplasmic reticulum. Int J Biochem Cell Biol 41:1817-1827. CrossRef Medline

Giorgi C, Ito K, Lin HK, Santangelo C, Wieckowski MR, Lebiedzinska M, Bononi A, Bonora M, Duszynski J, Bernardi R, Rizzuto R, Tacchetti C, Pinton P, Pandolfi PP (2010) PML regulates apoptosis at endoplasmic reticulum by modulating calcium release. Science 330:1247-1251. CrossRef Medline

Giorgi C, Baldassari F, Bononi A, Bonora M, De Marchi E, Marchi S, Missiroli S, Patergnani S, Rimessi A, Suski JM, Wieckowski MR, Pinton P (2012) Mitochondrial $\mathrm{Ca}(2+)$ and apoptosis. Cell Calcium 52:36-43. CrossRef Medline

Gomes LC, Di Benedetto G, Scorrano L (2011) During autophagy mitochondria elongate, are spared from degradation and sustain cell viability. Nat Cell Biol 13:589-598. CrossRef Medline

Goodyear RJ, Gale JE, Ranatunga KM, Kros CJ, Richardson GP (2008)
Aminoglycoside-induced phosphatidylserine externalization in sensory hair cells is regionally restricted, rapid, and reversible. J Neurosci 28 : 9939-9952. CrossRef Medline

Grimm S (2012) The ER-mitochondria interface: the social network of cell death. Biochim Biophys Acta 1823:327-334. CrossRef Medline

Gunter TE, Pfeiffer DR (1990) Mechanisms by which mitochondria transport calcium. Am J Physiol 258:C755-C786. Medline

Gunter TE, Gunter KK, Sheu SS, Gavin CE (1994) Mitochondrial calcium transport: physiological and pathological relevance. Am J Physiol 267: C313-C339. Medline

Hajnóczky G, Robb-Gaspers LD, Seitz MB, Thomas AP (1995) Decoding of cytosolic calcium oscillations in the mitochondria. Cell 82:415-424. CrossRef Medline

Hajnóczky G, Csordás G, Krishnamurthy R, Szalai G (2000) Mitochondrial calcium signaling driven by the IP3 receptor. J Bioenerg Biomembr 32 : 15-25. CrossRef Medline

Hansson MJ, Persson T, Friberg H, Keep MF, Rees A, Wieloch T, Elmér E (2003) Powerful cyclosporin inhibition of calcium-induced permeability transition in brain mitochondria. Brain Res 960:99-111. CrossRef Medline

Harris JA, Cheng AG, Cunningham LL, MacDonald G, Raible DW, Rubel EW (2003) Neomycin-induced hair cell death and rapid regeneration in the lateral line of zebrafish (Danio rerio). J Assoc Res Otolaryngol 4:219-234. CrossRef Medline

Hobbie SN, Akshay S, Kalapala SK, Bruell CM, Shcherbakov D, Böttger EC (2008) Genetic analysis of interactions with eukaryotic rRNA identify the mitoribosome as target in aminoglycoside ototoxicity. Proc Natl Acad Sci U S A 105:20888-20893. CrossRef Medline

Ichas F, Jouaville LS, Mazat JP (1997) Mitochondria are excitable organelles capable of generating and conveying electrical and calcium signals. Cell 89:1145-1153. CrossRef Medline

Jensen-Smith HC, Hallworth R, Nichols MG (2012) Gentamicin rapidly inhibits mitochondrial metabolism in high-frequency cochlear outer hair cells. PLoS One 7:e38471. CrossRef Medline

Jin Y, McEwen ML, Nottingham SA, Maragos WF, Dragicevic NB, Sullivan PG, Springer JE (2004) The mitochondrial uncoupling agent 2,4dinitrophenol improves mitochondrial function, attenuates oxidative damage, and increases white matter sparing in the contused spinal cord. J Neurotrauma 21:1396-1404. CrossRef Medline

Kalghatgi S, Spina CS, Costello JC, Liesa M, Morones-Ramirez JR, Slomovic S, Molina A, Shirihai OS, and Collins JJ (2013) Bactericidal antibiotics induce mitochondrial dysfunction and oxidative damage in mammalian cells. Sci Transl Med 5: 192ra185. CrossRef Medline

Karasawa T, Wang Q, David LL, Steyger PS (2011) Calreticulin binds to gentamicin and reduces drug-induced ototoxicity. Toxicol Sci 124:378387. CrossRef Medline

Kirichok Y, Krapivinsky G, Clapham DE (2004) The mitochondrial calcium uniporter is a highly selective ion channel. Nature 427:360-364. CrossRef Medline

Kobayashi T, Kuroda S, Tada M, Houkin K, Iwasaki Y, Abe H (2003) Calcium-induced mitochondrial swelling and cytochrome $\mathrm{c}$ release in the brain: its biochemical characteristics and implication in ischemic neuronal injury. Brain Res 960:62-70. CrossRef Medline

Korge P, Yang L, Yang JH, Wang Y, Qu Z, Weiss JN (2011) Protective role of transient pore openings in calcium handling by cardiac mitochondria. J Biol Chem 286:34851-34857. CrossRef Medline

Lane AZ, Wright GE, Blair DC (1977) Ototoxicity and nephrotoxicity of amikacin: an overview of phase II and phase III experience in the United States. Am J Med 62:911-918. CrossRef Medline

Li V, Brustovetsky T, Brustovetsky N (2009) Role of cyclophilin D-dependent mitochondrial permeability transition in glutamateinduced calcium deregulation and excitotoxic neuronal death. Exp Neurol 218:171-182. CrossRef Medline

Li Y, Johnson N, Capano M, Edwards M, Crompton M (2004) Cyclophilin-D promotes the mitochondrial permeability transition but has opposite effects on apoptosis and necrosis. Biochem J 383:101-109. CrossRef Medline

Loew LM, Carrington W, Tuft RA, Fay FS (1994) Physiological cytosolic $\mathrm{Ca} 2+$ transients evoke concurrent mitochondrial depolarizations. Proc Natl Acad Sci U S A 91:12579-12583. CrossRef Medline

Lorenz H, Hailey DW, Lippincott-Schwartz J (2006) Fluorescence protease 
protection of GFP chimeras to reveal protein topology and subcellular localization. Nat Methods 3:205-210. CrossRef Medline

Ma Q, Fang H, Shang W, Liu L, Xu Z, Ye T, Wang X, Zheng M, Chen Q, Cheng H (2011) Superoxide flashes: early mitochondrial signals for oxidative stress-induced apoptosis. J Biol Chem 286:27573-27581. CrossRef Medline

Mak DO, McBride S, Foskett JK (2001) ATP-dependent adenophostin activation of inositol 1,4,5-trisphosphate receptor channel gating: kinetic implications for the durations of calcium puffs in cells. J Gen Physiol 117: 299-314. CrossRef Medline

Maragos WF, Rockich KT, Dean JJ, Young KL (2003) Pre- or posttreatment with the mitochondrial uncoupler 2,4-dinitrophenol attenuates striatal quinolinate lesions. Brain Res 966:312-316. CrossRef Medline

Marks AR (1997) Intracellular calcium-release channels: regulators of cell life and death. Am J Physiol 272:H597-H605. Medline

Matlib MA, Zhou Z, Knight S, Ahmed S, Choi KM, Krause-Bauer J, Phillips R, Altschuld R, Katsube Y, Sperelakis N, Bers DM (1998) Oxygen-bridged dinuclear ruthenium amine complex specifically inhibits Ca2+ uptake into mitochondria in vitro and in situ in single cardiac myocytes. J Biol Chem 273:10223-10231. CrossRef Medline

Matsumoto S, Friberg H, Ferrand-Drake M, Wieloch T (1999) Blockade of the mitochondrial permeability transition pore diminishes infarct size in the rat after transient middle cerebral artery occlusion. J Cereb Blood Flow Metab 19:736-741. CrossRef Medline

Mattiasson G, Shamloo M, Gido G, Mathi K, Tomasevic G, Yi S, Warden CH, Castilho RF, Melcher T, Gonzalez-Zulueta M, Nikolich K, Wieloch T (2003) Uncoupling protein-2 prevents neuronal death and diminishes brain dysfunction after stroke and brain trauma. Nat Med 9:1062-1068. CrossRef Medline

McCormack JG, Halestrap AP, Denton RM (1990) Role of calcium ions in regulation of mammalian intramitochondrial metabolism. Physiol Rev 70:391-425. Medline

Mitra K, and Lippincott-Schwartz J (2010) Analysis of mitochondrial dynamics and functions using imaging approaches. Curr Protoc Cell Biol Chapter 4:Unit 4:25.1-25.21. CrossRef Medline

Murgia M, Giorgi C, Pinton P, Rizzuto R (2009) Controlling metabolism and cell death: at the heart of mitochondrial calcium signalling. J Mol Cell Cardiol 46:781-788. CrossRef Medline

Nakagawa T, Shimizu S, Watanabe T, Yamaguchi O, Otsu K, Yamagata H, Inohara H, Kubo T, Tsujimoto Y (2005) Cyclophilin D-dependent mitochondrial permeability transition regulates some necrotic but not apoptotic cell death. Nature 434:652-658. CrossRef Medline

Nakai J, Ohkura M, Imoto K (2001) A high signal-to-noise Ca(2+) probe composed of a single green fluorescent protein. Nat Biotechnol 19:137141. CrossRef Medline

Nguyen KT, García-Chacón LE, Barrett JN, Barrett EF, David G (2009) The $\mathrm{Psi}(\mathrm{m})$ depolarization that accompanies mitochondrial $\mathrm{Ca} 2+$ uptake is greater in mutant SOD1 than in wild-type mouse motor terminals. Proc Natl Acad Sci U S A 106:2007-2011. CrossRef Medline

Nicholls DG (2005) Mitochondria and calcium signaling. Cell Calcium 38: 311-317. CrossRef Medline

Nicholls DG (2009) Mitochondrial calcium function and dysfunction in the central nervous system. Biochim Biophys Acta 1787:1416-1424. CrossRef Medline

Nicholls DG, Chalmers S (2004) The integration of mitochondrial calcium transport and storage. J Bioenerg Biomembr 36:277-281. CrossRef Medline

Obholzer N, Wolfson S, Trapani JG, Mo W, Nechiporuk A, Busch-Nentwich E, Seiler C, Sidi S, Söllner C, Duncan RN, Boehland A, Nicolson T (2008) Vesicular glutamate transporter 3 is required for synaptic transmission in zebrafish hair cells. J Neurosci 28:2110-2118. CrossRef Medline

Oliveira JF, Silva CA, Barbieri CD, Oliveira GM, Zanetta DM, Burdmann EA (2009) Prevalence and risk factors for aminoglycoside nephrotoxicity in intensive care units. Antimicrob Agents Chemother 53:2887-2891. CrossRef Medline

Osman AA, Saito M, Makepeace C, Permutt MA, Schlesinger P, Mueckler M (2003) Wolframin expression induces novel ion channel activity in endoplasmic reticulum membranes and increases intracellular calcium. J Biol Chem 278:52755-52762. CrossRef Medline

Ou HC, Santos F, Raible DW, Simon JA, Rubel EW (2010) Drug screening for hearing loss: using the zebrafish lateral line to screen for drugs that prevent and cause hearing loss. Drug Discov Today 15:265-271. CrossRef Medline

Owens KN, Cunningham DE, MacDonald G, Rubel EW, Raible DW, Pujol R (2007) Ultrastructural analysis of aminoglycoside-induced hair cell death in the zebrafish lateral line reveals an early mitochondrial response. J Comp Neurol 502:522-543. CrossRef Medline

Pacher P, Csordás P, Schneider T, Hajnóczky G (2000) Quantification of calcium signal transmission from sarco-endoplasmic reticulum to the mitochondria. J Physiol 529:553-564. CrossRef Medline

Palmer AE, Jin C, Reed JC, Tsien RY (2004) Bcl-2-mediated alterations in endoplasmic reticulum $\mathrm{Ca} 2+$ analyzed with an improved genetically encoded fluorescent sensor. Proc Natl Acad Sci U S A 101:17404-17409. CrossRef Medline

Pandya JD, Pauly JR, Nukala VN, Sebastian AH, Day KM, Korde AS, Maragos WF, Hall ED, Sullivan PG (2007) Post-injury administration of mitochondrial uncouplers increases tissue sparing and improves behavioral outcome following traumatic brain injury in rodents. J Neurotrauma 24:798-811. CrossRef Medline

Patergnani S, Suski JM, Agnoletto C, Bononi A, Bonora M, De Marchi E, Giorgi C, Marchi S, Missiroli S, Poletti F, Rimessi A, Duszynski J, Wieckowski MR, Pinton P (2011) Calcium signaling around mitochondria associated membranes (MAMs). Cell Commun Signal 9:19. CrossRef Medline

Perry SW, Norman JP, Barbieri J, Brown EB, Gelbard HA (2011) Mitochondrial membrane potential probes and the proton gradient: a practical usage guide. Biotechniques 50:98-115. CrossRef Medline

Petronilli V, Cola C, Massari S, Colonna R, Bernardi P (1993) Physiological effectors modify voltage sensing by the cyclosporin A-sensitive permeability transition pore of mitochondria. J Biol Chem 268:21939-21945. Medline

Pinton P, Giorgi C, Siviero R, Zecchini E, Rizzuto R (2008) Calcium and apoptosis: ER-mitochondria $\mathrm{Ca} 2+$ transfer in the control of apoptosis. Oncogene 27:6407-6418. CrossRef Medline

Piot C, Croisille P, Staat P, Thibault H, Rioufol G, Mewton N, Elbelghiti R, Cung TT, Bonnefoy E, Angoulvant D, Macia C, Raczka F, Sportouch C, Gahide G, Finet G, André-Fouët X, Revel D, Kirkorian G, Monassier JP, Derumeaux G, Ovize M (2008) Effect of cyclosporine on reperfusion injury in acute myocardial infarction. N Engl J Med 359:473-481. CrossRef Medline

Raible DW, Kruse GJ (2000) Organization of lateral line system in embryonic zebrafish. J Comp Neurol 421:189-198. CrossRef Medline

Rizzuto R, Nakase H, Darras B, Francke U, Fabrizi GM, Mengel T, Walsh F, Kadenbach B, DiMauro S, Schon EA (1989) A gene specifying subunit VIII of human cytochrome coxidase is localized to chromosome 11 and is expressed in both muscle and non-muscle tissues. J Biol Chem 264: 10595-10600. Medline

Rizzuto R, Pinton P, Carrington W, Fay FS, Fogarty KE, Lifshitz LM, Tuft RA, Pozzan T (1998) Close contacts with the endoplasmic reticulum as determinants of mitochondrial Ca2+ responses. Science 280:1763-1766. CrossRef Medline

Rizzuto R, Marchi S, Bonora M, Aguiari P, Bononi A, De Stefani D, Giorgi C, Leo S, Rimessi A, Siviero R, Zecchini E, Pinton P (2009) Ca(2+) transfer from the ER to mitochondria: when, how and why. Biochim Biophys Acta 1787:1342-1351. CrossRef Medline

Santos F, MacDonald G, Rubel EW, Raible DW (2006) Lateral line hair cell maturation is a determinant of aminoglycoside susceptibility in zebrafish (Danio rerio). Hear Res 213:25-33. CrossRef Medline

Schinder AF, Olson EC, Spitzer NC, Montal M (1996) Mitochondrial dysfunction is a primary event in glutamate neurotoxicity. J Neurosci 16: 6125-6133. Medline

Schinzel AC, Takeuchi O, Huang Z, Fisher JK, Zhou Z, Rubens J, Hetz C, Danial NN, Moskowitz MA, Korsmeyer SJ (2005) Cyclophilin D is a component of mitochondrial permeability transition and mediates neuronal cell death after focal cerebral ischemia. Proc Natl Acad Sci U S A 102:12005-12010. CrossRef Medline

Schwarzländer M, Logan DC, Fricker MD, Sweetlove LJ (2011) The circularly permuted yellow fluorescent protein cpYFP that has been used as a superoxide probe is highly responsive to $\mathrm{pH}$ but not superoxide in mitochondria: implications for the existence of superoxide 'flashes'. Biochem J 437:381-387. CrossRef Medline

Shadel GS (2004) Coupling the mitochondrial transcription machinery to human disease. Trends Genet 20:513-519. CrossRef Medline 
Smaili SS, Russell JT (1999) Permeability transition pore regulates both mitochondrial membrane potential and agonist-evoked $\mathrm{Ca} 2+$ signals in oligodendrocyte progenitors. Cell Calcium 26:121-130. CrossRef Medline

Steyger PS, Burton M, Hawkins JR, Schuff NR, Baird RA (1997) Calbindin and parvalbumin are early markers of non-mitotically regenerating hair cells in the bullfrog vestibular otolith organs. Int J Dev Neurosci 15:417432. CrossRef Medline

Steyger PS, Peters SL, Rehling J, Hordichok A, Dai CF (2003) Uptake of gentamicin by bullfrog saccular hair cells in vitro. J Assoc Res Otolaryngol 4:565-578. CrossRef Medline

Stout AK, Raphael HM, Kanterewicz BI, Klann E, Reynolds IJ (1998) Glutamate-induced neuron death requires mitochondrial calcium uptake. Nat Neurosci 1:366-373. CrossRef Medline

Szabadkai G, Bianchi K, Várnai P, De Stefani D, Wieckowski MR, Cavagna D, Nagy AI, Balla T, Rizzuto R (2006) Chaperone-mediated coupling of endoplasmic reticulum and mitochondrial $\mathrm{Ca} 2+$ channels. J Cell Biol 175:901-911. CrossRef Medline

Szalai G, Krishnamurthy R, Hajnóczky G (1999) Apoptosis driven by IP(3)linked mitochondrial calcium signals. EMBO J 18:6349-6361. CrossRef Medline

Takei D, Ishihara H, Yamaguchi S, Yamada T, Tamura A, Katagiri H, Maruyama Y, Oka Y (2006) WFS1 protein modulates the free $\mathrm{Ca}(2+)$ concentration in the endoplasmic reticulum. FEBS Lett 580:5635-5640. CrossRef Medline

Tian L, Hires SA, Mao T, Huber D, Chiappe ME, Chalasani SH, Petreanu L, Akerboom J, McKinney SA, Schreiter ER, Bargmann CI, Jayaraman V, Svoboda K, Looger LL (2009) Imaging neural activity in worms, flies and mice with improved GCaMP calcium indicators. Nat Methods 6:875881. CrossRef Medline

Ton C, Parng C (2005) The use of zebrafish for assessing ototoxic and otoprotective agents. Hear Res 208:79-88. CrossRef Medline

Vance JE (1990) Phospholipid synthesis in a membrane fraction associated with mitochondria. J Biol Chem 265:7248-7256. Medline

Vergun O, Keelan J, Khodorov BI, Duchen MR (1999) Glutamate-induced mitochondrial depolarisation and perturbation of calcium homeostasis in cultured rat hippocampal neurones. J Physiol 519:451-466. CrossRef Medline
Wang Q, Steyger PS (2009) Trafficking of systemic fluorescent gentamicin into the cochlea and hair cells. J Assoc Res Otolaryngol 10:205-219. CrossRef Medline

Wang W, Fang H, Groom L, Cheng A, Zhang W, Liu J, Wang X, Li K, Han P, Zheng M, Yin J, Wang W, Mattson MP, Kao JP, Lakatta EG, Sheu SS, Ouyang K, Chen J, Dirksen RT, Cheng H (2008) Superoxide flashes in single mitochondria. Cell 134:279-290. CrossRef Medline

Wang X, Jian C, Zhang X, Huang Z, Xu J, Hou T, Shang W, Ding Y, Zhang W, Ouyang M, Wang Y, Yang Z, Zheng M, Cheng H (2012) Superoxide flashes: elemental events of mitochondrial ROS signaling in the heart. J Mol Cell Cardiol 52:940-948. CrossRef Medline

White RJ, Reynolds IJ (1997) Mitochondria accumulate Ca2+ following intense glutamate stimulation of cultured rat forebrain neurones. J Physiol 498:31-47. Medline

Wiley SE, Andreyev AY, Divakaruni AS, Karisch R, Perkins G, Wall EA, van der Geer P, Chen YF, Tsai TF, Simon MI, Neel BG, Dixon JE, Murphy AN (2013) Wolfram Syndrome protein, Minerl, regulates sulphydryl redox status, the unfolded protein response, and $\mathrm{Ca} 2+$ homeostasis. EMBO Mol Med 5:904-918. CrossRef Medline

Wortmann SB, Vaz FM, Gardeitchik T, Vissers LE, Renkema GH, SchuursHoeijmakers JH, Kulik W, Lammens M, Christin C, Kluijtmans LA, Rodenburg RJ, Nijtmans LG, Grünewald A, Klein C, Gerhold JM, Kozicz T, van Hasselt PM, Harakalova M, Kloosterman W, Barić I, et al. (2012) Mutations in the phospholipid remodeling gene SERAC1 impair mitochondrial function and intracellular cholesterol trafficking and cause dystonia and deafness. Nat Genet 44:797-802. CrossRef Medline

Xiao T, Roeser T, Staub W, Baier H (2005) A GFP-based genetic screen reveals mutations that disrupt the architecture of the zebrafish retinotectal projection. Development 132:2955-2967. CrossRef Medline

Zazueta C, Sosa-Torres ME, Correa F, Garza-Ortiz A (1999) Inhibitory properties of ruthenium amine complexes on mitochondrial calcium uptake. J Bioenerg Biomembr 31:551-557. CrossRef Medline

Zhao Y, Araki S, Wu J, Teramoto T, Chang YF, Nakano M, Abdelfattah AS, Fujiwara M, Ishihara T, Nagai T, Campbell RE (2011) An expanded palette of genetically encoded $\mathrm{Ca}(2)(+)$ indicators. Science 333:18881891. CrossRef Medline 